\title{
O PLANEJAMENTO URBANO NO SÉCULO XX: RESSONÂNCIAS DAS ESCOLAS URBANÍSTICAS NO CONTEXTO PÓS REVOLUÇÃO INDUSTRIAL E A HISTORICIZAÇÃO
} DA IDEIA DE CIDADE NO BRASIL

\author{
URBAN PLANNING IN THE TWENTIETH CENTURY: RESSONANCES OF THE POST \\ INDUSTRIAL REVOLUTION CONTEXT URBAN SCHOOLS'S AND THE \\ HISTORICIZATION OF A CITY IDEA IN BRAZIL
}

\author{
Mônica da Silva Cruz $^{1}$ \\ Regina Lúcia Gonçalves Tavares ${ }^{2}$
}

\section{Resumo}

Mapeadas as escolas urbanísticas contemporâneas à experiência do planejamento urbano no contexto pós-revolução industrial e as distintas posturas epistemológicas delas extraídas quando em questão a utilização dos espaços da cidade moderna, especialmente que tange à moradia urbana, busca-se compreender em que medida o saber ali insurgente atravessou o século XX e, em suas distintas escolas, gestoras de modelos de organização das cidades, foi capaz de historicizar o discurso urbanístico atual, conformando posturas políticas, jurídicas e administrativas que cercam o direito humano de viver em cidades. Aplicando-se o método da análise arqueológica do discurso de Michel Foucault, iniciou-se, mediante revisão bibliográfica, um mapeamento das escolas urbanísticas que influenciaram as políticas urbanas e as formas de organização das cidades ao longo do século XX, num recorte sobre os distintos discursos sobre a cidade. O problema que se coloca neste trabalho é: como a experiência do planejamento urbano, ora tomado como um acontecimento arqueológico, pode, historicamente, identificar as tendências discursivas que orientaram a experiência do planejamento urbano no Brasil? Os resultados permitiram encontrar um sistema de regularidades no qual reaparecem contraditórias práticas autoritárias e segregadoras, conformadoras de uma ideia de cidade construída segundo um modelo progressista, moldado no curso civilização industrial moderna.

Palavras-chave: Direito à Cidade; Planejamento Urbano; Arquelogia do Saber Urbanístico; Escolas Urbanísticas; Urbanismo Progressista.

\section{Abstract}

Mapped the urban schools relative to urban planning's experience in the post-industrial revolution context and the different epistemological postures extracted from them, when in question the use of modern city's spaces, especially in dealing with the urban dwelling, it seeks to understand to what extent the knowledge there insurgent, crossed the twentieth century and, in its different schools managers of organization cities' models, was able to historicize the

\footnotetext{
${ }^{1}$ Doutorado em Lingüística e Língua Portuguesa pela Universidade Estadual Paulista Julio de Mesquita Filho(UNESP/Araraquara). Professora associada I, do Departamento de Letras, Professora do Programa de Pós-Graduação em Letras (UFMA). Líder do Grupo de Pesquisa em Linguagem e Discurso do Maranhão (GPELD).Vice-coordenadora do projeto de Extensão Entretextos. E-mail: monicasc@ig.com.br

${ }^{2}$ Mestre em Direito e Instituições do Sistema de Justiça pela Universidade Federal do Maranhão (PPGDirUFMA). Professora da Universidade Federal de Juiz de Fora (UFJF). E-mail: rlg.t@hotmail.com
} 
current urban discourse, forming political, legal and administrative positions that surround the human right to live in cities. Applying the Michel Foucault's method of the archaeological analysis of discourse, by bibliographic review, a mapping of the urban schools that influenced the urban policies and the forms of organization of the cities throughout the twentieth century, in a clipping about the different discourses about the city. The problem that arises in this work is: how the experience of urban planning, now taken as an archaeological event, can historically identify the discursive tendencies that guided the experience of urban planning in Brazil? The results allowed us to find a system of regularities, in which contradictory authoritarian and segregating practices reappear, conforming an idea of a city built according to a progressive model, molded in modern industrial civilization's course.

Keywords: Right to the City; Urban Planning; Archeology of Urbanistic Knowledge; Urbanistic's Schools; Progressive Urbanism.

\section{INTRODUÇÃO}

Da compreensão do direito à moradia visto como um direito fundamental universal, porque relacionado à própria condição humana, a centralidade deste tema pode ser problematizada mediante sua decomposição em inúmeras variáveis que envolvem a questão da habitação. No caso da habitação urbana, isto se torna possível devido à refração de sentidos ou de significados que envolvem a investigação dos problemas da cidade, sobretudo aqueles mais relacionados ao uso e ocupação de seus espaços, segundo suas mais diferentes destinações.

Dito isto, explique-se que o presente trabalho é fruto de pesquisa acadêmica realizada no âmbito do Mestrado em Direito e Instituições do Sistema de Justiça da Universidade Federal do Maranhão, na qual foram investigados distintos discursos jurídicos sobre a cidade, para neles identificar processos de estruturação urbana, quando em pauta direito à moradia urbana no contexto da cidade de São Luís.

O presente artigo é assim um recorte daquela pesquisa e tem como objetivo o de refinar o conhecimento sobre a ideia de cidade, para tanto apresentando uma arqueologia do saber urbanístico, o que o faz por meio da exposição de especificidades relacionadas à cronologia da experiência do planejamento urbano no século XX, no propósito de identificar em que medida as escolas urbanísticas que influenciaram as políticas urbanas e as formas de organização das cidades ao longo do século XX inspiraram, ou ainda inspiram o modelo e os arranjos da cidade contemporânea, especialmente no caso do Brasil, sendo assim possível se historicizar a ideia de urbe 
Em suma, primeiro foram mapeados os diferentes discursos que emergiram, a partir do início do século XX, distinguidos nas escolas urbanísticas que, ao seu turno exerceram alguma influência sobre os modelos de cidade. Parte-se de uma contextualização histórica, situada no cenário europeu pós revolução industrial, tida como um acontecimento que redefiniu a forma de gestão das cidades envolvidas naquele processo de transformação, cujos reflexos findaram por persuadir uma nova epistemologia acerca da questão urbana no mundo inteiro e também no Brasil.

Desse modo, investigaram-se os caminhos percorridos pelos discursos urbanísticos do início do século XX, buscando-se entender em que medida tais posturas hegemonizam a política urbana no contexto atual, neste aspecto, buscando-se então significar o direito à moradia no ambiente das cidades a partir da questão do planejamento urbano, tomando-se como ponto de partida a síntese das ideias que propiciaram os fundamentos do urbanismo, o que possibilitou o teste da hipótese que atravessa todo trabalho, qual seja a de que aquela epistemologia urbana, nascida por ocasião da revolução industrial europeia, afeta os discursos que gravitam em torno da política urbana num contexto global.

Para tanto, foram utilizadas, como base de análise bibliográfica, as obras seminais de Françoise Choay (2015); Peter Hall (2016); Jane Jacobs (2014), dentre outros, autores cujas produções intelectuais sintetizam uma base crítica sobre a tarefa do planejamento urbano, sobretudo a partir do século XX, com isto buscando alcançar o objetivo teórico aqui exposto, qual seja o de mapear as diferentes bases discursivas sobre política urbana, empreendidas a partir do início do século XX, com vistas a definir as condições históricas que permitiram o surgimento de um discurso hegemônico capaz de definir um protótipo de cidade e, consequentemente, de política urbana.

No campo metodológico, a trajetória do trabalho, buscando outrora acontencimentalizar $^{3}$ o campo jurídico do discurso urbanístico, reconheceu que tal tarefa requereria a investigação de suas bases arqueológicas. Portanto, fez-se necessário esquadrinhar, inicialmente, as condições históricas que possibilitaram a experiência do saber

\footnotetext{
3 Utiliza-se aqui o termo "acontecimentalizar", tomando-se como referência o que Edgardo Castro conceitua como "acontecimentalização", em Michel Foucault: "Com esse neologismo, Foucault faz referência a uma forma de proceder na análise histórica, que se caracteriza, em primeiro lugar, por uma ruptura: fazer surgir a singularidade onde se está tentando fazer referência a uma constante histórica, a um caráter antropológico, ou a uma evidência que se impõe mais ou menos a todos." (CASTRO, 2016, p. 26)
} 
urbanístico, e de que maneira tal experiência possibilitou o aparecimento de uma retórica sobre a cidade, o que, especificamente, aqui se apresenta.

A questão do aparecimento do discurso e de seu acontecimento enquanto dado histórico oportuniza uma abordagem arqueológica que permita não a interpretação dos dados da pesquisa, mas a sua descrição como práticas (CASTRO, 2016, p. 41). Desse modo, optou-se pelo método arqueológico de Michel Foucault, pelo qual se buscou fazer a descrição dos discursos urbanísticos, porquanto se iniciando pelas regularidades que o tornaram historicamente possível.

Nesse sentido, tomando-se o discurso urbanístico como um acontecimento arqueológico, buscou-se em Michel Foucault (2012; 2014) o conceito de acontecimento ${ }^{4}$, aqui tomado como um conceito fundante da abordagem histórica da pesquisa arqueológica: "Em que quadro, de cronologia ampla, podem ser determinadas sequências distintas de acontecimentos?" (FOUCAULT, 2012, p. 9).

Castro (2016, p. 24) distingue o acontecimento, na arqueologia foucaultiana, em dois sentidos que se interrelacionam: o primeiro, o acontecimento arqueológico, seria aquele pelo qual a noção de acontecimento se relaciona intimamente com a noção de ruptura histórica, ou seja, "a mutação de uma episteme à outra é pensada como acontecimento radical que estabelece uma nova ordem do saber". (CASTRO, 2016, p. 25).

Por esse conceito o autor busca explicar que um saber, um objeto ou uma verdade irrompe sempre em decorrência de um conjunto de fatores, os quais não se vinculam por meio de relações de causas e efeitos. Esses fatores podem ser de distinta natureza, assim como podem irromper em momentos muito diferentes, configurando o que o filósofo chamou dispersão.

Desse tema a análise enunciativa tenta liberar-se, para restituir os enunciados à sua pura dispersão; para analisá-los em uma exterioridade sem dúvida paradoxal, já que não remete a nenhuma forma adversa de interioridade; para considerá-los em sua descontinuidade, sem ter de relacioná-los por um desses deslocamentos que os põe fora de circuito e os tornam inessenciais, a uma abertura ou a uma diferença mais fundamental; para apreender sua própria irrupção no lugar e no momento em que se produziu para reencontrar sua incidência de acontecimento. (FOUCAULT, 2012, p. 142).

\footnotetext{
${ }^{4}$ A arqueologia descreve os enunciados como acontecimentos. [...] A descrição, em termos de acontecimento, em lugar das condições gramaticais ou das condições de significação, leva em consideração as condições de existência que determinam a materialidade própria do enunciado. (CASTRO, 2016, p. 25).
} 
O acontecimento arqueológico, inserindo uma "novidade histórica" (CASTRO, 2016, p. 24) no âmbito dos saberes, relaciona-se com o segundo sentido de acontecimento em Foucault, que seria a noção de acontecimento discursivo. O acontecimento discursivo ajuda a compreender arqueologicamente os enunciados como práticas históricas que se reatualizam e, por isto, ostentam uma natureza de regularidade: "Existe claramente uma relação entre esses dois sentidos: as novidades instauram novas formas de regularidade". (CASTRO, 2016, p. 24).

Para Michel Foucault, a positividade do discurso, caracterizada por sua unidade através do tempo, presente nas falas de muitos autores, em diferentes contextos, define um campo de "continuidades temáticas, translações de conceitos" que vão desempenhar o papel do que o autor chama de a priori histórico. (FOUCAULT, 2012, p. 155).

O "a priori histórico" efetivamente não designa a condição de validade dos juízos, nem busca estabelecer o que torna legítima uma asserção, mas sim as condições históricas dos enunciados, suas condições de emergência, a lei de sua coexistência com outros, sua forma específica de ser, os princípios segundo os quais se substituem, transformam-se e desaparecem". (CASTRO, 2016, p. 21).

Para se compreender o conceito de a priori histórico em Foucault, torna-se necessário apartá-lo da noção de tradição e associá-lo à noção de arquivo, ou seja, à lei daquilo que pode ser enunciado, ou o próprio sistema que rege o aparecimento e o desaparecimento das falas, e que não depende do sujeito (MANZI, 2014, p. 211), isto porque, para o autor, a história está essencialmente influenciada pelo discurso e não pela subjetividade.

São essas formações e regularidades que conformam os discursos - estes últimos não pensados a partir de uma subjetividade que os constitua e, tampouco, pela regularidade de atos fundadores, mas surgidos com o apagamento da intencionalidade dos sujeitos - que são tomados pela linguagem: "É como se o sujeito assumisse o caráter inconsciente da estrutura que determina suas ações" (MANZI, 2014, p. 205).

É a episteme a matriz racional ou a condição de possibilidade de determinada ordem, possibilitando o surgimento de discursos e sua organização em uma época, que introduz a ideia de a priori histórico em Foucault. Por intermédio do a priori histórico pode-se explicar a recorrência de assuntos, discursos e verdades em uma determinada época, em certas sociedades.

Porquanto, especula-se o a priori histórico dos saberes urbanísticos, levando-se em conta o solo que o tornou possível, ou sua episteme (MANZI, 2014), ou seja, as condições de possibilidade que promoveram o aparecimento daquele saber, seus enunciados e os objetos com os quais ele se ocupa. Parte-se do pressuposto arqueológico de que sua manifestação não 
depende da manipulação de um sujeito ativo, mas de "ligações sucessivas diversas de cada prática discursiva". (MANZI, 2014, p. 210).

O objetivo de Foucault pode, assim, ser resumido enquanto um fazer aparecer das práticas discursivas, tirando toda e qualquer referência a uma subjetividade psicológica ou constituinte. O que visa são os modos de sucessão, de encadeamento e de coexistência de enunciados no campo em que eles emergem e se especificam. Neste contexto, o a priori histórico que nos propõe Foucault está diretamente relacionado à questão da arqueologia enquanto uma descrição de práticas específicas. Uma descrição que tem como ponto de referência o arquivo [...]. (MANZI, 2014, p. 211).

Desse modo, é para uma percuciente análise da episteme urbanística, surgida nas primeiras décadas do século XX, que se vai buscar o acontecimento arqueológico do discurso urbanístico, segundo os processos múltiplos que o constituem, de partida compreendendo sua estrutura multifacetada (CASTRO, 2016), como, por exemplo, a ressignificação espacial das cidades deflagrada a partir de um acontecimento histórico: o aumento populacional decorrente do crescimento das indústrias e do esvaziamento do campo.

\section{A PRIORI DO SABER URBANÍSTICO DO SÉCULO XX}

O inchaço das cidades, outrora medievais, ocasionado pela revolução industrial, sobretudo no cenário europeu, foi um dos gatilhos para que, em meados do século XIX, se iniciasse um processo de especulação territorial, mediante o qual os espaços urbanos passaram a ser fragmentados numa lógica funcional a demandar, por parte da administração pública, certa regulação. "A liberdade individual, exigida como condição para o desenvolvimento da economia industrial, revela-se insuficiente para regular as transformações de construção e urbanismo, produzidas justamente pelo desenvolvimento econômico". (BENEVOLO, 2015, p. 567).

Para Benevolo (2015), a crise do modelo liberal da cidade - que trouxe a reboque desordem, falta de saneamento e higiene, inabitabilidade e, ainda, surtos de cólera - dá-se numa conjuntura histórica em que um novo modelo de cidade pós-liberal é pensado para atender aos propósitos higienistas das classes dominantes que, à sua vez, passaram a contar com o apoio do Poder Público de maneira que:

A liberdade completa, concedida às iniciativas privadas, é limitada pela intervenção da administração - que estabelece os regulamentos e executa as obras públicas [...]. A administração gere um espaço que é um mínimo necessário para fazer funcionar o conjunto da cidade [...]. A propriedade administra o restante. [...] A utilização dos terrenos 
urbanizados depende dos proprietários individuais. (BENEVOLO, 2015, p. 573).

Trata-se de um a priori histórico especificamente contextualizado numa fase que se seguiu à Comuna de Paris 5 , na qual, vitoriosa a elite dominante, conduzida por Napoleão III, foram deflagradas diversas reformas no contexto urbano europeu: “[...] Napoleão III pretende fazer de Paris "a capital das capitais". Ele define uma política de urbanismo ambiciosa e para empreendê-la escolhe Haussmann [...]" (HAROUEL, 1998, p. 112).

Numa visão retrospectiva da formação destas ações urbanísticas, toma-se a revolução industrial como um marco histórico. Identificada cronologicamente a partir de metade do século XVIII, a revolução industrial findou por mudar os rumos da história e ressignificar sobretudo o ambiente das cidades, que passaram a ser rota de destino das populações campesinas, as quais para ela seguiam em busca de novas oportunidades de trabalho.

Vários fatores desencadearam a reordenação das cidades e dos espaços urbanos: o crescimento populacional decorrente do aumento da natalidade e da diminuição da mortalidade e o aumento da expectativa de vida de 35 para 50 anos, do que decorreu o surgimento de novas gerações a reclamarem novos postos de trabalho; a demanda das indústrias pela força de trabalho dos operários, ocasionando um fluxo migratório dos campos; o desenvolvimento das estradas e meios de transporte. Todos, fatores que impulsionaram o crescimento prematuro das cidades, sem que estas acompanhassem, na mesma velocidade, a conformação de estruturas urbanas que pudessem acomodar este novo contingente populacional (BENEVOLO, 2015).

O resultado de todas estas transformações, sobretudo no ambiente da Inglaterra, lugar de onde eclodiram os primeiros problemas sociais decorrentes da sociedade moderna industrial, foi a formação de uma nova estratificação social urbana, cuja camada mais pobre era formada pelos operários das fábricas que, disputando com as outras camadas os espaços das cidades, findavam por instalarem-se em cortiços os mais próximos possíveis de seus locais de trabalho, fato que tornava a questão habitacional um grande problema a se resolver: "alguns milhares de ricos e alguns milhões de indivíduos de classe média foram levados a um estreito contato com milhões de pobres e indigentes". (HALL, 2016, p. 71).

Cada quarto, nessas podres e fétidas moradias coletivas, aloja uma família, muitas vezes duas. Um fiscal sanitário registra em seu relatório

\footnotetext{
5 "A Comuna de Paris representou uma curta demonstração revolucionária de emancipação e autogestão do proletariado francês, fundada em uma política antiburguesa, reveladora de uma luta política de classes. Durou pouco, especificamente 72 dias, tendo sido em seguida derrotada pela política burguesa, fortemente amparada pelas forças do governo francês e do exército" (VIANA, 2011, p. 75).
} 
haver encontrado, num porão, o pai, a mãe, três crianças e quatro porcos! Noutro, um missionário encontrou um homem com varíola, uma mulher na convalescença de seu oitavo parto e as crianças andando de um lado para o outro, seminuas e cobertas de imundície. Aqui estão sete pessoas morando numa cozinha no subsolo, e ali mesmo morta jaz uma criancinha. Em outro local estão uma pobre viúva, seus três filhos e o cadáver de uma criança morta há treze dias. Pouco antes, o marido, um cocheiro, havia se suicidado. (MEARNS, 1883, apud HALL 2015, p. 38).

Ademais disto, a própria ocupação do solo tornou-se uma categoria mercantil a ser explorada, nascendo aí um campo de continuidade temática pelo qual os primeiros esquemas de planejamento urbano foram pensados no sentido de se derrubarem os cortiços, entregando à iniciativa privada a construção de moradias fora do perímetro urbano. (HALL, 2016, p. 181182).

Os economistas ensinam a limitar a intervenção pública em todos os setores da vida social, e também no urbanístico. Adam Smith aconselha os governos a vender os terrenos de propriedade pública, para pagar suas dívidas. Estes conselhos são recebidos de bom grado pelas classes dominantes, que têm interesse em fazer valer, também no campo imobiliário, a liberdade da iniciativa privada, isto é, têm condições de aproveitar a desordem urbana sem sofrer-lhe as consequências. Mas algumas desvantagens de ordem física (o congestionamento do tráfego, a insalubridade, a feiura) tornam intolerável a vida das classes subalternas, e ameaçam, a partir de certo momento em diante o ambiente em que vivem todas as outras classes. (BENEVOLO, 2016, p. 552).

Em Paris, por exemplo, tais reformas, capitaneadas pelo prefeito Georges Eugène Haussmann, o Barão de Haussmann ${ }^{6}$, foram destinadas à valorização e embelezamento de determinados espaços para moradia e deleite da classe privilegiada, o que motivou a regularidade de práticas conformadas por políticas de higienização, demolições e

\footnotetext{
${ }^{6}$ A reforma urbanística que se realizou em Paris, entre 1853 e 1870, pelo Barão Georges Haussmann, teve como propósito a remodelação da cidade, estratificando-a e expulsando para subúrbios a classe operária: "Esse remanejamento do tecido espacial parisiense foi uma resposta da classe dominante às jornadas operárias de junho de 1848. Lefebvre afirma que a segregação dos trabalhadores foi uma estratégia da burguesia de Paris para frear a democracia urbana nascente impulsionada pelas lutas populares, uma vez que, naquele momento, essa ordem política embrionária representava uma ameaça real aos interesses políticos das classes dominantes. [...] o urbanismo segregacionista colocado em prática por Haussmann atuou contra a cidade, já que contribuiu para anular aquilo que é (ou deveria ser) peculiar e mais característico da vida urbana: os espaços de encontro e de convívio das diferentes classes e grupos sociais. [...] No curso desse processo, os subúrbios, inicialmente criados para abrigar apenas a classe operária, passaram a exercer forte poder de atração sobre as camadas burguesas parisienses, esvaziando o centro da cidade em benefício dos escritórios e de um uso quase puramente comercial. [...] Graças ao remanejamento espacial, Paris se subordinou gradualmente à lógica e ao ritmo capitalista de produção do espaço. A especulação imobiliária desempenhou papel fundamental nesse cenário, ao atuar em favor da crescente mercantilização do solo, e assim, em lugar das relações de valor de uso, relações de valor de troca passam a prevalecer". (TRINDADE, 2012, p. 141-142).
} 
suburbanização da classe operária, com o consequente esgarçamento do tecido urbano (GARBOSSA; SILVA, 2016).

O barão Haussmann, homem desse Estado bonapartista que se erige sobre a cidade a fim de tratá-la cinicamente como despojo (e não apenas como a arena) das lutas pelo poder, substitui as ruas tortuosas, mas vivas, por longas avenidas, e os seus bairros sofridos, mas animados, por bairros aburguesados. Se ele abre boulevards, se arranja espaços vazios não é pela beleza das perspectivas. É para "pentear Paris com as metralhadoras" (Benjamin Péret). O célebre barão não esconde isso. (LEFEBVRE, 2011, p. 25)

Segundo Harouel (1998), as intervenções do Barão de Haussmann criaram uma Paris cortada por grandes artérias, avenidas, boulevares, ruas largas, inseridas na paisagem urbana à custa da demolição de prédios e cortiços. Foram ações empreendidas em nome da circulação, do embelezamento e, também, da manutenção da ordem possibilitada por um espaço aberto, propício a impedir o surgimento de novos motins: "O urbanismo de Haussmann induz à formação, numa parte da cidade, de um espaço da burguesia" (HAROUEL, 1998, p. 113).

Para Lefebvre (2011), é a revolução industrial verdadeiro ponto de partida para se refletir sobre as cidades modernas, porque conformadora de grupos sociais que geram 0 emprego econômico do capital e, por isto, reatualizadora dos contornos de uma nova sociedade, esta representada por uma burguesia progressista, "dotada de instrumentos ideológicos adequados a esse crescimento racional, que caminha na direção da democracia e que substitui a opressão pela exploração" (LEFEBVRE, 2011, p. 23).

A revolução industrial é quase imediatamente seguida por um explosivo crescimento demográfico das cidades, primeiro na Inglaterra, depois na França e na Alemanha. Após 1850, enquanto a população mundial se quadruplicava, a população urbana se multiplicava por dez. (GARBOSSA; SILVA, 2016 p. 30)

O crescimento das cidades em tamanho e população, para Yamawaki e Salvi (2013), foi o que impulsionou o surgimento de movimentos que se propuseram a estudá-las, a ponto de consistirem um dado a priori das escolas ou linhas de pensamento arranjadas com o propósito de resolver, ou mesmo buscar amenizar os problemas decorrentes da urbanização desordenada. Algumas dessas escolas, no contexto europeu e norte-americano, ao longo do século XX, chegaram, inclusive, a se opor à vida urbana, para estas, um locus necessariamente, agregador do caos (YAMAWAKI; SALVI, 2013, p. 44).

Lidar com essa produção e essas práticas exteriores aos ambientes profissionais não é, de toda maneira, tarefa trivial no interior de uma panorâmica das abordagens do planejamento e da gestão urbanos, uma vez que se está diante de uma memória intelectual (memória das lutas e 
das ideias, táticas e estratégias associadas) dispersa e, normalmente, nãoformalizada. (SOUZA, 2013, p. 118).

Françoise Choay (2015, p. 2) afirma que o termo urbanismo, definido como a "ciência e teoria da localização humana", foi cunhado somente no início do século XX, momento no qual a expansão da cidade industrial já era uma realidade consolidada, o que deprecava, em termos de respostas, novas posturas críticas e reflexivas sobre os problemas urbanos daí advindos, a consolidarem regularidades de uma prática que conformasse uma nova perspectiva de gestão das cidades.

Chega-se então, segundo a abordagem metodológica desta explanação, a um acontecimento arqueológico (FOUCAULT, 2012), uma mudança na episteme do saber urbanístico, a estabelecer uma nova ordem urbana, orientada por um processo de ruptura histórica com os padrões das cidades tradicionais.

Para Peter Hall (2015, p. 24), esta linha demarcatória, qual seja a de estudar a política urbana a partir de um ideal teórico formulado sobretudo até a metade do século XX, justifica-se pelo fato que tais ideias consistiram numa espécie de reação à cidade do século XIX e aos impactos causados pela revolução industrial, sobretudo no contexto da Europa e dos Estados Unidos $^{7}$, e que até hoje influenciam o processo de gestão dos espaços.

O estudo destas ideias é sistematizado por Choay (2015) em duas etapas: o préurbanismo e o urbanismo. Para a autora, esta divisão considera o problema de situar o estudo das teorias urbanísticas, como dito, a partir dos desafios evidenciados no ambiente urbano com o advento da revolução industrial e as transformações incutidas nas cidades ao longo do século XIX.

Do ponto de vista quantitativo, a revolução industrial é quase imediatamente seguida por um impressionante crescimento demográfico das cidades, por uma drenagem dos campos em benefício de um desenvolvimento urbano sem precedentes. $O$ aparecimento e a importância desse fenômeno seguem a ordem e o nível de industrialização dos países. A Grã-Bretanha é o primeiro palco desse movimento, sensível desde os recenseamentos de 1801; no restante do continente europeu, a França e a Alemanha perfilham-se a partir dos anos 1830. (CHOAY, 2015, p. 3)

De fato, as questões que surgiam com o vertiginoso aumento populacional das cidades e a consequente demanda por moradia, ocorridas num ambiente urbano cujas estruturas ainda

\footnotetext{
${ }^{7}$ Para o jurista francês Jean-Louis Harouel, a explosão demográfica das cidades se dá por dois fatores, quais sejam, o crescimento da população ativa associado ao esvaziamento do setor primário: "Esse grande inchaço da população citadina é consequência de progressos científicos e técnicos realizados a partir da metade do século XVIII. É a Europa ocidental que desencadeia o processo, logo seguida e posteriormente ultrapassada pelos Estados Unidos" (HAROUEL, 1998, p. 101).
} 
obedeciam às necessidades de cidades medievais, provocaram, segundo Choay (2015), novas posturas de observação e reflexão que resultaram em abordagens científicas sobre o meio urbano, seja por investidas meramente descritivas ou que obedeciam a um senso críticonormativo, seja por um pensamento político fundador de uma sociologia urbana na qual se visava discutir a situação da classe trabalhadora na Inglaterra, esta última encontrando em Friederich Engels seu principal expoente (CHOAY, 2015).

Muito embora todas as linhas de pensamento sobre política urbana no século XX tenham tomado como base de reflexão da cidade industrial e seus problemas o pensamento econômico e filosófico do século XVIII (Rousseau, Adam Smith, Hegel), estas se dividiram em duas posturas epistemológicas

A primeira rejeitava o imperativo de uma nova ordem urbana, mas partia do ponto comum sobre o qual tomava a realidade das cidades sob uma circunstância de desordem, segundo Françoise Choay (2015), (ou pseudodesordem, nas palavras da autora), a reclamar a construção de um ideal de reordenação e de planejamento (o que se pode chamar, segundo Marcelo Lopes de Souza (2013) de uma postura convencional sobre o ordenamento urbano).

A segunda distinguia a insurgência de uma conjuntura política e social totalmente diversa daquela que se encerrou com a revolução industrial, o que reclamaria um rompimento não-convencional com as antigas bases de organização do espaço.

Para o estudo de tais escolas de planejamento urbano, Marcelo Lopes de Souza (2013) se inspira em Françoise Choay (2015), assim selecionando aquelas de índole progressista ou modernista, culturalista e naturalista, e vai adiante propondo uma tipologização a partir da qual ele as classifica de modo mais abrangente, criando uma dicotomia que finda por opor posturas abrangentes acerca da lógica do desenvolvimento e organização das cidades.

Com efeito, Souza (2013) especializa a classificação de Choay levando em conta as estratégias de intervenção urbana, privilegiando assim a leitura das escolas de planejamento outrora selecionadas, mediante a oposição entre o convencional e o não-convencional (SOUZA, 2013). Explique-se:

Convencionais seriam as modalidades de planejamento e gestão que não apresentassem nenhum nível significativo de crítica em relação à referida interpretação do desenvolvimento urbano como modernização da cidade (caso não só do Urbanismo Modernista, mas de quase todas as vertentes urbanísticas e, mais amplamente, do planejamento Urbano ao longo da maior parte do século XX); não-convencionais seriam os enfoques que, em graus e de maneiras diferentes, afastaram-se dessa ortodoxia, seja em nome de considerações de ordem ecológica, seja em nome de 
constelações afeitas a busca de uma maior integração social nas cidades. (SOUZA, 2013, p. 119)

Daquela primeira concepção, que assume uma perspectiva convencional do urbano, construída sob a episteme da desordem, foram formuladas, segundo Choay (2015), dois tipos de projeções espaciais, ou dois modelos urbanísticos: o primeiro, como um que pauta sua reflexão numa dimensão utópica, sobre a qual a ordem deve ser restaurada nostalgicamente, mediante a recuperação das formas urbanas do passado (os culturalistas e os naturalistas), ainda que ressignificadas; o segundo, como um modelo que reclama formas urbanas que atendam às necessidades do futuro (os progressistas).

Já Hall (2015) classifica as ideias que dominaram o planejamento urbano no século XX como linhas de conduta ou ideias-chave. Neste propósito, o autor destaca como primeira linha de conduta aquela que cunhou o conceito de cidade-jardim, conceito este que se decompôs refratariamente em outras variantes da mesma manifestação ideal ${ }^{8}$.

Outras linhas de conduta são destacadas por Hall (2015) como aquelas que reformulam a estrutura urbana, pensando-a a partir da conformação de cidades regionais, planejadas harmoniosamente pela via do uso dos recursos naturais de cada lugar.

Uma terceira linha de conduta mencionada por Hall (2015) é aquela que, segundo o autor, delineia sua ideia de planejamento urbano a partir da projeção de uma cidade moderna ideal, planejada para um desenvolvimento ideal de uma ordem social programada.

Para Peter Hall, entretanto, os limites de tais ideias-chave não podem ser fixados de maneira indelével, pelo fato de que, no seu entendimento, muitas destas tradições findam por se mesclar, reatualizando práticas definidas em modelos múltiplos.

Voltemos assim, por razões metodológicas, à categorização proposta por Françoise Choay, em razão de que a estrutura classificatória a partir da qual a autora desenvolve seus estudos sobre as ideias e as práticas urbanísticas do século XX, permitem delinear as diferentes práticas discursivas que contribuirão com a presente análise arqueológica.

Deste modo, Choay prossegue em sua classificação destacando que os modelos de urbanismo - citados pela autora a partir dos seguintes protótipos: o modelo progressista; o modelo culturalista; e o modelo naturalista -, assim vistos como uma reação aos problemas urbanos e o formato adotado pelas cidades a partir do século XX, geraram contra si uma outra

\footnotetext{
${ }^{8}$ As cidades-jardim, segundo Hall $(2015$, p. 26), representavam um modelo pelo qual boa parcela da população dos centros urbanos se deslocariam para uma espécie de "constelação de novas cidades" formadas no entorno do centro urbano, distantes de seu burburinho. Tal modelo repercutiu em diferentes arquétipos, dentre eles imagens de recolonização do campo, ou a configuração de espaços suburbanos.
} 
espécie de reação, esta nominada pela autora como uma crítica de segundo grau (CHOAY, 2015, p. 35).

Seria o que Marcelo Lopes de Souza (2013) chama de posturas abrangentes acerca da lógica do desenvolvimento das cidades, numa perspectiva não-convencional, formuladas sobretudo a partir da segunda guerra mundial.

Choay, ao se referir à crítica da crítica, abordou-as, distinguindo-as em duas grandes direções: a tecnotopia e a antrópolis (CHOAY, 2015, p. 35). Ou seja, na primeira direção, a tecnotopia realiza uma abordagem visionária da cidade, segundo a qual os processos de articulação do espaço urbano se sujeitam ao conhecimento dos avanços tecnológicos disponíveis: "A cidade torna-se um belo objeto técnico, inteiramente determinado e encerrado" (CHOAY, 2015, p. 37).

Num segundo momento, estas críticas ao urbanismo convencional recebem a contribuição de uma escola de planejamento urbano que se articula sob uma perspectiva mais humanista, que Choay classifica de antrópolis. Aqui, neste ponto, insere-se uma crítica radical do urbanismo progressista.

Essa crítica, que pode ser qualificada de humanista, desenvolveu-se fora do meio especializado dos urbanistas e dos construtores. É o resultado do trabalho de um conjunto de sociólogos, historiadores, economistas, juristas, psicólogos, pertencentes, sobretudo, aos países anglo-saxões. (CHOAY, 2015, p. 38)

Ainda para a citada autora, a crítica humanista pode ser analisada a partir de três abordagens metodológicas distintas, quais sejam: a localização humana como enraizamento espaço-temporal; o ponto de vista da higiene mental; e a análise estrutural da percepção humana (CHOAY, 2015, p. 38).

É a partir desta sistematização trabalhada por Françoise Choay que se vão sintetizar os discursos urbanísticos, entre protótipos convencionais - o modelo progressista; o modelo culturalista; e o modelo naturalista - e não-convencionais - o modelo humanista.

\section{O modelo progressista}

Os urbanistas pré-progressistas (final do século XVIII até início do século XIX), como Victor Consideránt, Charles Fourier e Júlio Verne, para citar alguns, e os urbanistas progressistas (final do século XIX até metade do século XX), como Tony Garnier, Georges Benoit-Lèvy, Walter Gropius, Charles-Édouard Jeanneret (Le Corbusier) e Stanislav Gustavovitch Strumilin, foram 
precursores das ideais de cidades-modelo, construídas a partir de rígidos padrões estéticos, que tinham por princípio a organização, a essência, a função e a uniformização.

De fato, o urbanismo progressista consistia numa corrente idealista, inspirada numa fórmula de exatidão de um modelo urbano moderno, concebido indistintamente para todo o grupo humano (HAROUEL, 1998): "O esquema urbano é considerado válido em qualquer lugar, pois ele é concebido para o homem-padrão" (HAROUEL, 1998, p. 121).

Segundo Yamawaki e Salvi (2013), tratava-se de um ideal que projetava a criação de cidades descentralizadas, de baixa densidade, setorizadas de acordo com suas funções e atividades, mediante a organização de zonas de usos predominantes, o que estimulou o esvaziamento das áreas centrais e, consequentemente, a concepção de habitação em grandes áreas periféricas.

A metáfora da máquina, na realidade, seria aplicada, no limite, a toda a cidade, a qual também deveria "funcionar" como uma máquina. Não é à toa que, ao lado da preocupação com a higiene, a obsessão com a ordem base da harmonia social, seja um dos pilares do projeto de modernização das cidades preconizado pelos modernistas. (SOUZA, 2013, p. 126)

A ideia central deste pensamento acha-se representada pela obra de Le Corbusier ${ }^{9}$, grande expoente deste modelo de urbanismo, cuja direção fundamental era a ordenação da cidade e a persecução do bem-estar postos como antítese à mixórdia da cidade industrial. Foi o arquiteto Le Corbusier que codificou a ideia de um planejamento chamado modernista, segundo o qual as cidades deveriam ser construídas a partir das necessidades elementares do homem (trabalhar, habitar, circular e recrear) e mediante categorias que as relacionavam com o modo de produção industrial (SOUZA, 2013, p. 126).

São cidades pensadas a partir de uma proposta de organização e conformação de espaços, que se materializam por meio de protótipos de cidades standard, como por exemplo: a cidade-jardim ou a cidade-operária, (Tony Garnier e Georges Benoit-Lèvy); os edifícios do futuro (Walter Gropius, este fortemente influenciando a arquitetura estadunidense); as cidadesmodelo (Le Corbusier e Stanislav Gustavovitch Strumilin). Todos estes exemplos tomados como prospectos padronizadores de um mesmo modelo de racionalidade que inadmite a

\footnotetext{
${ }^{9}$ Arquiteto pintor e urbanista, Charles-Edouard Jeanneret (Le Corbusier), nasceu na Suíça, em 1887, e faleceu na França, em 1965. Foi o redator da Carta de Atenas, na qual fundados os princípios dos modelos de construção contemporânea que se materializa tomando o humano a partir de um padrão de necessidades tipo, para quem a casa seria uma máquina de morar. Influenciou arquitetos e engenheiros do mundo inteiro, tendo sido professor dos brasileiros Oscar Niemayer e Lúcio Costa (LE CORBUSIER, 2004).
} 
espontaneidade ou mesmo a diversidade, porque as toma como sinônimo de desordem, caos e insegurança. (CHOAY, 2015, p. 163-197).

O urbanismo progressista traduz-se numa forma de pensar a cidade a partir de um dado a priori ligado à estética e à higiene: "Uma classificação rigorosa instala em locais distintos o habitat, o trabalho, a cultura e o lazer". (CHOAY, 2015, p. 9). Integram uma lógica funcional a partir da qual o bem-estar geral é seccionado mediante critérios onde o progresso social possa ser decifrado por estratégias de embelezamento.

Essa importância atribuída à impressão visual indica bem o papel da estética na concepção da ordem progressista. É preciso, no entanto, sublinhar a austeridade dessa estética, onde lógica e beleza coincidem. [...]. Em certos casos, a ordem específica da cidade progressista é expressa com uma precisão de detalhes e uma rigidez que eliminam a possibilidade de variantes ou de adaptações a partir de um mesmo modelo. (CHOAY, 2015, p. 9).

O modelo progressista localiza na Carta de $\operatorname{Atenas}^{10}$ a primeira grande referência dos padrões urbanísticos e de sua ordenação (MILARÉ, 2014), que se evidenciam com ideias concernentes à abolição das ruas e à valorização de espaços fragmentados intramuros, governados por uma ordem vocacionada a um tipo ideal de humanidade que valoriza a estética, a saúde, a higiene e a funcionalidade da cidade.

Essa imagem do homem-tipo inspira a Carta de Atenas, que analisa as necessidades humanas universais no quadro de quatro grandes funções: habitar, trabalhar, locomover-se, cultivar o corpo e o espírito. Tal é a base que deve permitir a determinação, a priori, com toda certeza do que Gropius chama "o tipo ideal de localização humana". (CHOAY, 2015, p. 21).

Para Corbusier, o urbanista deveria ser necessariamente o arquiteto, ou seja, aquele agente detentor de um saber específico, de conhecimentos estritos e técnicas capazes de reconfigurarem o espaço e promover a higiene urbana; conforme Foucault, o sujeito autorizado a proferir verdades, no caso, sobre o espaço urbano. Sua principal contribuição para os temas que até hoje gravitam em tono da questão da organização dos espaços urbanos foram: a "classificação das funções urbanas, multiplicação dos espaços verdes, criação de protótipos funcionais, racionalização do habitat coletivo" (CHOAY, 2015, p. 184).

Daí a construção dos conjuntos residenciais passou a ser uma solução para o apagamento da "feiura" dos cortiços e consequente embelezamento das cidades. Para Hall (2016), alguns historiadores afirmam que essas estratégias eram motivadas mais pelo medo do

\footnotetext{
10 "A partir de 1928, o modelo progressista encontra seu órgão de difusão num movimento internacional, o grupo dos C.I.A.M., em 1933, esse grupo propõe uma formulação doutrinária sobre o nome de Carta de Atenas. Esta constitui, portanto, o bem comum dos urbanistas progressistas." (CHOAY, 2015, p. 20)
} 
que pela preocupação com a penúria com que vivia a classe operária. De fato, era uma estratégia de separação de funções urbanas que, tendo como vetor principal o saneamento dos núcleos citadinos dos problemas decorrentes da pobreza, gerou outros problemas: o da mobilidade e "a grande praga da monotonia". (JACOBS, 2015, p. 158).

É nesta conjuntura de regularidades que se gesta o modelo do urbanismo progressista, cuja harmonia planejada, a qual Hall, crítico feroz da metodologia corbusiana, se contrapõe afirmando que "gente não é escapo, e não se pode reduzir a sociedade à ordem de um mecanismo de relógio" (HALL, 2016, p. 290).

Os críticos do modelo progressista encontraram nas ideais de Corbusier uma espécie de reação ao descontrole estético e sanitário das grandes cidades industriais. Sua arquitetura cunhava um modelo aberto, "rompido por vazios e verdes", modelador de um racionalismo técnico tendente a padronizar estruturas urbanas funcionais, mediante a ressignificação do homem com o seu habitat a partir de protótipos preestabelecidos (CHOAY, 2015, p. 8).

O habitante da cidade corbusiana tornou-se um tipo, uma ideia, cujas necessidades eram pensadas com base em arquétipos ordeiros, alheios às contingências de cada realidade particular. Segundo Peter Hall, Brasília seria o protótipo da cidade corbusiana, para cujo empreendimento Juscelino Kubitscheck [...]

Recorreu a seu velho amigo, o arquiteto Oscar Niemayer. O Instituto de arquitetos do Brasil protestou; fazia-se necessário um concurso público. Niemeyer, evidentemente, participou da comissão julgadora, que, após uma deliberação de apenas três dias, escolheu para ordenar um dos mais vastos exercícios urbanísticos do século XX o plano de Lúcio Costa, outro pioneiro do movimento arquitetural moderno no Brasil. O trabalho por ele apresentado constava de desenhos à mão livre, feitos sobre cinco cartolinas de tamanho médio; nem uma única projeção populacional, ou análise econômica, ou programação de uso do solo, nem uma só maquete, nem um só desenho a esquadro ou compasso. O júri gostou da "grandiosidade"; "Desde o início ficou patente que Brasília estava fadada a ser uma cidade de arquiteto antes que de um planejador urbano". (HALL, 2016, p. 302)

Para Hall (2016, p. 291-292), a cidade progressista de Le Corbusier deveria nascer de uma arquitetura automatizada, orientada por uma espécie de ordem "ideal, centralizada e despótica", cujo espírito devesse ser arrojado e "sem remorsos" para "dominar e compelir a plebe" a uma planificação utópica, desprovida de preocupação com sua contextualização.

Mais do que a cultura, é a geometria que ordena o modelo progressista, segundo premissas arquiteturais de organização do espaço e que, de alguma forma, a distingue do modelo culturalista. 


\section{O modelo culturalista}

A escola culturalista, cujos principais representantes foram William Morris (final do século XVIII até início do século XIX) e Ebenezer Howard e Raymond Unwin (final do século XIX até metade do século XX), contrapondo-se à ideia do homem ideal, habitante de uma cidade ideal, perseguida pelos modernistas, pensava o habitat a partir de outras premissas, quais sejam, a da "vida comunitária" e a do "atendimento às necessidades psicológicas" (YAMAWAKI; SALVI, 2013, p. 44).

Esta linha de pensamento concebia os processos de urbanização a partir dos indicadores do bem-estar, da qualidade de vida e do contato com a natureza (YUMI; SALVI, 2013, p. 44), por meio dos quais a análise da cidade, mediante uma projeção tipológica, seria substituída por uma projeção relacional, que toma por base as estruturas urbanas do passado (CHOAY, 2015).

O que os culturalistas propuseram foi um retorno aos valores urbanísticos do passado europeu pré-industrial que, segundo eles, muito mais apropriadamente, permitia a realização individual e o desenvolvimento da cultura, valores estes que, todavia, deveriam estar conciliados com as necessidades do presente, o que, para Choay (2015,), resulta em modelo nostálgico de tipos, portanto, não muito distanciado da tipologia progressista.

Chega-se assim, por canais diferentes, ao mesmo resultado que no urbanismo progressista. Ao utopismo progressista, opõe-se o utopismo nostálgico, e à religião do funcionalismo o culto dos valores ancestrais, cujos modos de funcionamento a história e a arqueologia desvendaram. (CHOAY, 2015, p. 29)

A se conformar como terceira linha de pensamento convencional sobre as estruturas urbanas, juntamente com as outras duas citadas, está a escola naturalista.

\section{O modelo naturalista}

A escola naturalista teve como representante icônico Frank Lloyd Wright, cujas ideias propunham uma cidade plenamente integrada à natureza, a conformar uma utopia ainda muito mais radical do que a utopia do modelo culturalista.

Os defensores dessa escola urbanista acusavam o urbanismo artificial da cidade industrial de deslocar o homem de sua real natureza, relação esta que só poderia ser resgatada a partir de uma ideia de planejamento que permitisse com que as pessoas pudessem ter de volta o contato com a terra. 
O urbanismo naturalista se projetou a partir do desenho de um modelo específico, por meio do qual a arquitetura deveria se submeter à natureza: a Broadacre City ${ }^{11}$, um "sistema acêntrico, composto de elementos pontuais, inseridos numa rica rede circulatória". (CHOAY, 2015, p. 30).

Para Yumi e Salvi, muito embora reatualizada historicamente a predominância do pensamento progressista, estas três escolas, mesmo com propostas distintas para se pensar a questão urbana e o planejamento das cidades, apresentavam em comum um mesmo parecer sobre a cidade, utopicamente estático e padronizado, ou seja, apresentaram "propostas de projeto e desenho rígidos, que primavam pela estética, tentando encontrar soluções para as cidades ideais" (YAMAWAKI; SALVI, 2013, p. 44).

Esses três modelos (progressista, culturalista e naturalista) não tiveram as mesmas ressonâncias na prática. O estudo das realizações concretas do urbanismo traz à luz, como se pode adivinhar, a grande superioridade numérica das aglomerações progressistas. O modelo naturalista só pode exprimir-se muito parcialmente, sobretudo nos Estados Unidos, em formas suburbanas. O modelo culturalista continua a inspirar a construção de cidades novas na Inglaterra; fora dali, só deu lugar a experiências limitadas (certas reconstruções e algumas estações turísticas). (CHOAY, 2015, p. 33).

Aos modelos convencionais de urbanização, se irão contrapor os movimentos urbanistas não-convencionais, dos quais, para efeito de balizar o presente estudo arqueológico, será tomado como protótipo de análise o urbanismo humanista ${ }^{12}$.

\section{O urbanismo humanista}

Realizando um contraponto, muito especialmente à corrente progressista que dominou e ainda domina o campo da política urbana no mundo, e que prega um urbanismo em tese, pensado para um elemento humano igualmente em tese, o urbanismo humanista, preconizado

\footnotetext{
11 "A escolha deste nome não vem do fato de que Broadacre está fundada na unidade mínima de um acre para cada indivíduo, mas, fato muito importante, de que, surgida no seio da democracia, Broadacre é a cidade natural da liberdade no espaço, do reflexo humano". (CHOAY, 2015, p. 241)

${ }^{12}$ A tecnotopia, como posição não-convencional de planejamento será aqui desprestigiada para efeito da presente análise porque se trata de uma escola de planejamento que estuda mais particularmente as estruturas técnicas de edificação e os projetos que diretamente se relacionam com os progresso técnicos da arquitetura e da engenharia (CHOAY, 2015, p. 35). Ademais, para efeito de se recortar o acontecimento arqueológico do discurso urbanístico, a escola humanista poderá oferecer um contraponto satisfatório ao urbanismo convencional.
} 
por Patrick Geddes ${ }^{13}$ e Lewis Mumford ${ }^{14}$, parte da realidade concreta e visa reintegrar o homem concreto no planejamento urbano (CHOAY, 2015).

Geddes filia-se à abordagem metodológica do urbanismo humanista intuitivo, segundo a qual o planejamento urbano deve estar atento à localização humana como enraizamento espaço-temporal (CHOAY, 2015), o que o dissociaria de modelos preconcebidos de cidades-tipo.

À rigidez do planejamento progressista de Le Corbusier, o urbanismo humanista propõe "a suavidade, a alterabilidade e a flexibilidade de soluções que hoje tornam possíveis as técnicas de construção" (CHOAY, 2015, p. 40).

Com efeito, o método da intuição geddesiana é solidário com uma concepção do tempo e da história como criação permanente $e$ continuidade. Constitui, assim, a antítese da posição dos urbanistas progressistas, para quem a modernidade coloca em jogo um processo de ruptura e de descontinuidade. (CHOAY, 2015, p. 42)

Esta mesma linha de pensamento é transplantada para a América Latina, para onde, na década de 60, o arquiteto inglês John Turner levou sua concepção de que o problema habitacional não poderia ser resolvido de cima para baixo, uma vez que não se materializaria sem a colaboração da comunidade envolvida nos processos de deterioração urbana: "Turner foi o primeiro a descobrir o que a investigação múltipla sociológica e antropológica provaria mais tarde: que a verdade era quase o avesso do que rezava a sabedoria convencional" (HALL, 2016, p. 367).

Do ponto de vista da higiene mental, um contraponto de grande expressão em meio aos estudiosos do urbanismo se insurgiu contra as técnicas do urbanismo progressista. Tal tendência crítica acha-se representada nos escritos de Jane Jacobs (2014), em seu "Morte e Vida nas Grandes Cidades", obra na qual a autora encampa uma defesa das grandes cidades a partir da valorização de sua diversidade ${ }^{15}$.

\footnotetext{
${ }^{13} \mathrm{O}$ escocês Patrick Geddes, muito embora fosse biólogo de formação, dedicou-se ao estudo da história, da sociologia e das cidades. Para Geddes, a tarefa de urbanificação demanda uma pesquisa sobre todos os fatores que incidem sobre aquela ação, por isto, para ele, a história tem fundamental importância para se pensar a remodelação ou a criação de bairros. Seu pensamento foi, em seguida, desenvolvido pelo historiador e sociólogo Lewis Mumford, para quem os urbanistas progressistas exerceram um papel de mutiladores da cidade. (CHOAY, 2015)

${ }^{14}$ Discípulo de Geddes, Mumford "vê a cidade como o centro nevrálgico do nosso tempo; dá para o problema do urbanismo todas as suas dimensões culturais e históricas e recusa-se a fechá-lo num quadro exclusivamente técnico" (CHOAY, 2015, p. 285)

${ }^{15}$ Jane Jacobs, escritora, jornalista e urbanista autodidata, nasceu em 1916 nos Estados Unidos e faleceu em 2006, no Canadá. Pode ser apontada como grande difusora de alternativas para os projetos hegemônicos de renovação urbana: "com seu ataque de pro-inferno-com-essas-suas-casas, lançado tanto contra os corbusianos, como contra os planejadores cidades-jardim, e por seu apelo pela volta à
} 
Para Jacobs (2014), o urbanismo progressista jamais conseguirá dominar ou mesmo decifrar "o comportamento misterioso e indomável das cidades" (JACOBS, 2014, p. 12), de modo que decifrá-las requer a observação de suas variáveis, a partir de seus próprios significantes.

Trata-se, de um princípio onipresente: o da "necessidade que as cidades têm de uma diversidade de uso mais complexa e densa, que possibilite entre eles uma sustentação mútua e constante, tanto econômica, quanto social" (JACOBS, 2014, p. 13).

Esta visão é compartilhada por Jan Ghel (2015), arquiteto e urbanista dinamarquês contemporâneo, para quem a dimensão humana é um ponto de partida universal; é o que a cidade tem de mais importante, de modo que a diversidade é estruturante para que as relações decorrentes desta dimensão não se percam.

A discussão sobre a "morte e vida" nas cidades, desafiadoramente levantada em 1961 pelo livro de Jane Jacobs, em grande parte lidava com a gradual perda de oportunidades dos espaços urbanos de funcionarem como ponto de encontro. Ainda que a discussão tenha continuado desde então, em muitos lugares a vida na cidade continuou a ser espremida para fora do espaço da cidade. (GHEL, 2015, p. 26).

Jan Ghel sugere um modelo de cidade que chama de "cidade saudável". A cidade saudável de Jan Ghel (2015) é uma cidade viva, cujos espaços são mais densos, humanizados e revitalizados, ou seja, cidades cujo planejamento leva em conta, sobretudo, sua dimensão humana e as consequências positivas de uma ocupação pensada sob aquelas bases.

A vida da cidade não acontece por si mesma ou se desenvolve de forma autônoma, simplesmente como resposta à alta densidade. Essa questão requer uma abordagem concentrada e bem mais variada. Cidades vivas requerem estrutura urbana compacta, densidade populacional razoável, distâncias aceitáveis para serem percorridas a pé ou de bicicleta e espaço urbano de boa qualidade. A densidade, que representa quantidade, deve ser combinada com a qualidade sob a forma de bons espaços urbanos. (GEHL, 2015, p. 69)

De fato, a cidade que prioriza a mistura de funções e que se volta para dentro de si mesma, densificando seus espaços, racionaliza a demanda por mais atividades de urbanificação, abertura de vias e pavimentação, saneamento, transporte público e mais consumo de energia, variáveis do modelo adverso, o que resulta numa paisagem urbana de aspecto sustentável, cujo formato é sugerido da seguinte forma:

Cidades baseadas nesse método são construídas em torno de sistemas leves sobre trilhos, circundadas por empreendimentos de densidade relativamente alta. Essa estrutura é condição para oferecer um número

densidade e aos usos mistos da terra, característicos da cidade tradicional não planejada." (HALL, 2016, p. 377) 
suficiente de moradias e locais de trabalho localizados a uma razoável distância das estações, a ser percorrida a pé ou de bicicleta. (GEHL, 2015, p. 107)

O autor, muito embora pontue distinções entre as necessidades das cidades ricas e das cidades pobres ao redor do mundo, ratifica que tais medidas se tornam mais urgentes nas cidades menos desenvolvidas, em razão do fosso existente entre ricos e pobres, o que, para ele tem funcionado como um limitador de oportunidades e de heterogeneidade (GEHL, 2015), pelo que aponta a sustentabilidade social como um indicador subjacente às cidades vivas.

À concepção progressista de planejamento urbano mediante planos de standardização geradores de homogeneidade e indiferenciação, o urbanismo humanista opõe-se com argumentos de monotonia, tédio e desdiferenciação psíquica (CHOAY, 2015, p. 45). Passa então o princípio da heterogeneidade a conduzir as ideias de planejamento a partir de um diferencial humanístico.

Uma terceira abordagem humanista centra-se numa metodologia pela qual o planejamento urbano deve atentar para uma análise estrutural da percepção humana. Trata-se de uma abordagem segundo a qual a percepção da cidade não pode ser reduzida à uma percepção estética, mas, a partir das consciências que nela se inserem, o que, segundo Choay (2015, p. 48), faz ruir qualquer planejamento a priori.

Este entendimento defende que as ideias dos habitantes da cidade e suas considerações acerca da forma como vivenciarão suas necessidades de espaço no contexto urbano, deve se impor previamente a qualquer ideia de planificação.

Com isto, delineadas as características das principais linhas de pensamento sobre a gestão urbana, a partir do século XX, percebe-se, no cenário mundial, a regularidade de uma prática hegemônica de uma ordem urbanística planificadora, ilustrada, sobretudo, nos ideais da escola progressista, o que foi, com algumas particularidades, confirmada no contexto brasileiro.

\section{A EXPERIÊNCIA DO PLANEJAMENTO URBANO NO BRASIL}

A formação dos aglomerados urbanos no Brasil ocorre no mesmo momento histórico em que as cidades europeias vivenciavam os efeitos da revolução industrial, pelo que, antes disso, no contexto histórico do Brasil Colônia, as vilas e cidades eram fundadas mais por conta de ações estratégicas da metrópole: geralmente situadas junto à costa (GARBOSSA; SILVA, 2016), adentrando para o interior da colônia na medida em que as ações exploratórias 
mudavam o seu foco (mineração, agricultura e pecuária) ou surgiam necessidades outras relacionadas à segurança local.

Mesmo após a independência, o fortalecimento das oligarquias regionais permitiu a manutenção da concentração de vastos espaços de terras em mãos de poucos produtores rurais dedicados à monocultura. Esse período foi caracterizado, sobretudo, pelo incremento da produção e exportação do café - esta uma das maiores fontes de renda do Brasil já emancipado politicamente da Metrópole - e pela formação das indústrias no ambiente das cidades, acarretando, para os espaços urbanos em formação, um forte êxodo populacional, o que resultou, precocemente, num processo de concentração e expansão pontual. (YAMAWAKI; SALVI, 2013).

Crescia no Brasil o trabalho assalariado e, por outro lado, enfraquecia-se, com a proibição do tráfico, a estrutura de produção amparada na mão-obra escrava, num cenário institucionalizado pela Lei da Terra (Lei 601/1850) que possuía como objetivos principais, além de organizar a posse e a propriedade de terra no Brasil, mediante registro e ações de demarcação, também promover a geração de frentes de trabalho pela via da contratação de mão-de-obra assalariada. (DEÁK, 2010).

O processo de conversão de uma população campesina para uma população urbana, sobretudo escravos libertos, não abarcados pelos processos de remodelação do trabalho nas lavouras monocultoras, foi uma questão de tempo.

Foi nesse contexto, com a abolição da escravidão, a instituição do trabalho livre e assalariado e a proclamação da República, que foram empreendidas as primeiras ações de intervenção urbana, fortemente influenciadas pelos movimentos higienistas europeus (YAMAWAKI; SALVI, 2013), que também aqui na nossa realidade, foram deflagradores de um processo de periferização da moradia e de "especialização na divisão do espaço urbano" (YAMAWAKI; SALVI, 2013, p. 317), o que, numa sociedade capitalista como a do Brasil, fariam surgir espaços estruturalmente divididos de acordo com a função que seus habitantes ocupassem na escala de produção.

O traço elitista sobre o qual se consagrou a urbanização das cidades no Brasil orientouse por um processo coerente com as estruturas de sua formação histórica e social, cristalizada num duro padrão de estratificação, historicamente sedimentado na instituição da escravidão, sobre a qual se conformou um arquétipo de diferenciação política e social, em um sistema de hierarquia patrimonialista, vertical e personalizadora da norma, a obedecer outros imperativos que não o da cidadania (DAMATTA, 1996). 
Sérgio Buarque de Hollanda (1995) chama de "revolução brasileira de $1888^{16 " ~ a ~}$ transmutação do Brasil rural para o Brasil urbano, a partir da qual, segundo o autor, fez-se possível identificar um processo de urbanização baseado em fundamentos agrários e personalistas, capaz de cristalizar uma conjuntura por meio da qual dificilmente um Estado Democrático de Direito, tal qual mais tarde idealizado pelos legisladores constitucionais de 1988, seria implementado com vigor. Este é igualmente o entendimento da urbanista Ermínia Maricato:

Apesar de se urbanizar apenas no século XX (em 1900, segundo o IBGE, apenas $10 \%$ da população brasileira morava em cidades), o Brasil carrega, no processo de urbanização, características decorrentes das mazelas de sua relação dependente e subordinada e também algumas características da nossa "formação social". A herança escravocrata e o desprestígio do trabalho, o patriarcalismo e a condição inferiorizada da mulher, o patrimonialismo e a privatização da esfera pública, o personalismo e a rejeição às relações impessoais e profissionais, o clientelismo e a universalização da política do favor, contrariamente ao reconhecimento dos direitos, a tradição autoritária negando a cidadania, estão presentes em cada $\mathrm{m}^{2}$ da cidade periférica. (MARICATO, 2014, p. 134-135)

Ainda para Hollanda (1995), a frouxidão da estrutura social e a falta de hierarquia organizada foram características fundantes da falta de coesão na gestão da vida social e política do Brasil. Para o autor, este traço deveu-se ao fato de que os povos ibéricos para cá trouxeram um ideal de livre arbítrio, de autossuficiência e de responsabilidade pessoal que pouco, ou nada, possibilitavam um acordo coletivo viável, a não ser por uma força externa que se the impunha por preponderância (HOLLANDA, 1995).

Exemplo de intervenções urbanísticas inauguradoras de uma gestão urbana planificada, no Brasil do início do século XX, é protótipo paradigmático a remodelação da cidade do Rio de Janeiro, no contexto sob o qual se deu a revolta da vacina.

Segundo Sevcenko (2010), a Revolta da Vacina, ocorrida em 1904, foi um movimento de insurgência da população da cidade do Rio de Janeiro contra a política tecnocrática de higienização e remodelação da então Capital Federal, capitaneada pelo Prefeito Pereira Passos que, inspirado no replanejamento e embelezamento estratégico de Paris, empreendido pelo Barão de Haussmann, executou uma campanha de limpeza dos centros urbanos da cidade, para empreendimentos de regeneração e imposição de um novo padrão estético.

\footnotetext{
${ }^{16}$ Trata-se da chamada por Hollanda, 'grande revolução brasileira', cujo marco histórico foi a abolição da escravidão e que deflagrou um processo de urbanização corroborado pelo estímulo à monocultura do café e do açúcar, a gerar uma maior dependência dos centros urbanos, que passaram a ser o centro de gravidade da vida social e política do Brasil (HOLLANDA, 1995).
} 
O ato de insurgência contra as táticas políticas daquele processo de intervenção urbana ficou conhecido como Revolta /da Vacina, porque seu gatilho se deu em razão do início de uma ampla e maciça campanha de vacinação, de submissão incondicional, utilizada pela administração pública local para justificar o asseio da cidade, mediante demolições e transferência das populações mais humildes para locais mais periféricos.

Foi nesse contexto que observamos o conjunto de transformações que combinaram com a reformulação da sociedade brasileira, constituindo a sua feição material mais aparente e ostensiva, o processo de Regeneração, ou seja, a metamorfose urbana da capital federal, acompanhada das medidas de saneamento e da redistribuição espacial dos vários grupos sociais. Esse processo de reurbanização trouxe consigo fórmulas particularmente drásticas de discriminação, exclusão e controle social, voltadas contra os grupos destituídos da sociedade. (SEVCENKO, 2010, p. 120)

Lima Barreto (2013) manifesta em Os Bruzundangas, escrito em 1923, uma crônica satírica de um país fictício, cujas estruturas sociais desiguais, as elites, os governos, as instituições e as práticas sociais à moda do Brasil, são analisadas pela ótica de um narrador; um visitante estarrecido com os hábitos daquela sociedade. Trata-se de uma narrativa provocativa que nos permite uma reflexão - pode-se dizer ainda bastante atual - acerca de nossas instituições republicanas.

[Sobre os vaticinadores de Bruzundanga] Não há como discutir com eles, porque todos se guiam por ideias feitas, receitas de julgamentos e nunca se aventuram a examinar por si qualquer questão, preferindo resolvê-las por generalizações quase sempre recebidas de segunda ou terceira mão, diluídas e desfiguradas pelas sucessivas passagens de uma cabeça para outra cabeça. (BARRETO, 2013, p. 22)

A propósito de ser um cronista de sua época, Lima Barreto, no auge da Primeira República (1889 a 1930), já identificava padrões hegemônicos e elitistas no processo de urbanização das cidades brasileiras, sendo o Rio de Janeiro, então sede do Governo Federal, o lócus de sua análise crítica, na qual reconhecia certa imitação dos modelos de urbanização europeus, mesmo que à custa do elemento humano. Distinguia, desde o século passado, a proposta de um urbanismo progressista que, priorizando protótipos estéticos, esquadrinhava o formato de uma cidade asseada.

E os da frente, os cinco mil de cima, esforçavam por obter as medidas legislativas favoráveis à transformação da cidade e ao enriquecimento dos patrimônios respectivos com indenizações fabulosas e especulações sobre terrenos. Os Haussmanns pululavam. Projetavam-se avenidas; abriam-se nas plantas squares, delineavam-se palácios, e, como complemento, queriam também uma população catita, limpinha, elegante e branca: cocheiros irrepreensíveis, engraxates de libré, criadas 
louras, de olhos azuis, com o uniforme como se viam nos jornais de moda da Inglaterra. (BARRETO, 2014, p. 99)

Para Maricato (2013), as reformas urbanas que se implementaram no Brasil, a partir do final do século XIX, foram responsáveis por lançar as bases de um modelo urbanista moderno, ou progressista, associado a um cruel ingrediente de periferização, orientado por um processo de diferenciação social.

Realizavam-se obras de saneamento básico para eliminação das epidemias, ao mesmo tempo em que se promovia o embelezamento paisagístico e eram implantadas as bases legais para um mercado imobiliário de corte capitalista. A população excluída desse processo era expulsa para os morros e franjas da cidade. (MARICATO, 2013, p. 17)

Flávio Villaça compreende que as ações do Estado sobre o espaço urbano no Brasil podem ser estudadas dividindo-as em três períodos distintos: “O que vai até 1930, o que vai de 1930 até a década de 1990 e o que se inicia nessa década". (VILLAÇA, 2010, p. 182).

Com uma economia predominantemente agrária até os anos 30 do século XX, o Brasil ainda possuía incipientes indústria e comércio, de modo que, no ambiente das cidades, a questão da moradia era basicamente resolvida pela construção de vilas operárias pelas próprias empresas, num artifício de ordenar a habitação de seus trabalhadores próximo às fábricas, em terrenos de baixo custo: "O fornecimento de moradia pela própria empresa diminuía as despesas dos operários com sua própria sobrevivência, permitindo que os salários fossem rebaixados" (KOWARICK, 1993, p. 34).

A extraordinária rentabilidade da exploração cafeeira, a partir dos anos finais do século XIX, permitiu expandir bastante a economia do país. Grandes fortunas, formadas pelo café, promoveram um começo de industrialização. Para atender às necessidades de mão-de-obra da agricultura e até mesmo da indústria nascente, o país recorreu à imigração europeia. A economia do café provocou pois a expansão e diversificação da população, o crescimento das cidades e o surgimento de uma classe média urbana, pequena, porém bastante ativa no processo político. (STEDILE; SAMPAIO, 2003, p. 16).

A partir dos anos de 1930 e com o fim da República Velha, inicia-se, muito embora tardiamente, de maneira mais robusta, o processo de industrialização no país, como uma das condições de possibilidade do aparecimento das massas urbanas ${ }^{17}$. 0 crescimento caótico de uma população citadina resultou num aumento de pressão pela oferta de habitações populares.

17 "Os primeiros organismos que se dedicaram à construção de casas populares em maior escala foram os diversos institutos de aposentadoria e pensão (industriários, comerciários, bancários, etc.) criados a partir de 1930. Entretanto, essas entidades operavam normalmente de maneira fragmentária, sendo sua atividade, nesse campo, considerada secundária e atingindo um pequeno número de seus associados." (DE AZEVEDO, 1988, p. 101) 
Tais fenômenos ocorreram paralelamente à valorização dos terrenos fabris e residenciais que torna, do ponto de vista da empresa, antieconômica a construção de vilas para "seus" operários, ainda mais quando, com a aceleração do fluxo migratório, acumula-se um excedente de força de trabalho na cidade. (KOWARICK, 1993, p. 34-35)

O que ocorre, a partir daí, é o que Kowarick (1993) chama de transferência do custo de moradia para o trabalhador e do custo dos serviços de infraestrutura urbana para o Estado: "Desse momento em diante, as vilas operárias tendem a desaparecer e a questão da moradia passa a ser resolvida pelas relações econômicas no mercado imobiliário" (KOWARICK, 1993, p. 35).

Até o final da segunda guerra mundial, o Brasil viveu o que Plínio de Arruda Sampaio chama de "desenvolvimento para dentro" (STEDILE; SAMPAIO, 2003, p. 18), período no qual a indústria foi fortalecida para aquecer o mercado interno que, diretamente atrelado ao processo de produção de moradia, era incentivado pelo poder público a construir casas "para serem alugadas a baixos alugueis, ou mesmo oferecidas gratuitamente aos seus operários" (BONDUKI, 1994, p. 715). Para Nabil Bonduki (1994), estes foram os primeiros investimentos de grande porte no campo da política de habitação no país.

A produção de moradia operária no período de implantação e consolidação das relações de produção capitalistas e de criação do mercado de trabalho livre, que corresponde aos primórdios do regime republicano, era uma atividade exercida pela iniciativa privada, objetivando basicamente a obtenção de rendimentos pelo investimento na construção ou aquisição de casas de aluguel. (BONDUKI, 1994, p. 712)

Foi realmente a partir dos anos de 1950 que o Brasil passou a adotar, de forma mais acentuada, uma política de valorização do capital estrangeiro, por meio da qual se dilatou um enfraquecimento dos empreendimentos e da capacidade industrial interna, associada a uma estrangeirização do capital circulante (FURTADO, 1992).

Este processo de recrudescimento de uma velha política de dependência econômica da iniciativa, da tecnologia e do capital estrangeiro, refletiu sobremaneira na experiência do planejamento urbano do Brasil.

Ao manter a população do campo à margem do desenvolvimento, o regime só deu a ela uma chance: emigrar para a cidade. Ela o fez, de modo massivo, inchando as cidades e transpondo para elas a miséria característica da zona rural. (STEDILE; SAMPAIO, 2003, p. 20)

Para Celso Furtado (1992), o processo de aceleração da economia, ainda que voltada ao mercado externo, e a facilidade de acesso aos bens de consumo - evidentemente àqueles que compunham as classes sociais mais privilegiadas -, foi o que permitiu com que os brasileiros que ocupavam os estratos mais favorecidos da sociedade pudessem conviver e, de certo modo, 
até legitimar o efeito colateral deste modelo de desenvolvimento, sintomatizado por gritantes injustiças sociais.

No que tange ao processo de produção de moradia, a política urbana também atendeu aos interesses daquele modelo de crescimento, mediante o direcionamento de recursos financeiros a um mercado habitacional, orquestrado, a partir de $1964^{18}$, pelo Banco Nacional de Habitação.

A motivação principal para a criação do Banco Nacional da Habitação foi de ordem política. Segundo os mentores do BNH, o desempenho marcante na produção de casas populares deveria permitir ao regime militar emergente obter a simpatia de largos setores das massas que constituíram o principal apoio social do governo populista derrubado em 1964. Nesse projeto, igualmente encontrava-se implícita a ideia de que a casa própria poderia desempenhar um papel ideológico importante, transformando o trabalhador de contestador em "aliado da ordem". (DE AZEVEDO, 1988, p. 109)

Maricato (2013) compreende que o processo de urbanização e o perfil das grandes cidades no Brasil foram extremamente afetados pelas políticas de moradia implantadas pelo Sistema Financeiro de Habitação que, na medida em que instituía a aquisição da casa própria, mediante financiamento como o modus operandi por excelência de promover o aparelhamento das cidades, sobretudo no que tange à questão da produção de habitação para abarcar seu contingente populacional, por outro lado, não cuidou em abranger aqueles que não podiam acessar tal via hegemônica de acesso à moradia.

Assim, as camadas empobrecidas eram cada vez mais empurradas para "áreas completamente inadequadas ao desenvolvimento urbano racional, penalizando seus moradores e também todos os contribuintes que tiveram que arcar com a extensão da infraestrutura" (MARICATO, 2013, p. 21).

Este formato de política urbana findou por cristalizar um modelo de cidade estratificada, fragmentada e periferizada, que se construiu invariavelmente ao longo do tempo, a ponto de sedimentar uma ideologia hegemônica de banalização de cidades conformadas por espaços de distinção, naturalmente ratificada por uma prática administrativa que corrobora com tal realidade, produtora de ambientes onde há intensa atuação urbanística embasada em forte esquema legislativo, contrapostos a outros desprovidos de equipamentos urbanos que permitam um habitat ao menos razoável.

\footnotetext{
18 Para Ermínia Maricato "foi com o Banco Nacional de Habitação (BNH) integrado ao Sistema Financeiro de Habitação SFH, criados pelo regime militar a partir de 1964, que as cidades brasileiras passaram a ocupar o centro de uma política destinada a mudar seu padrão de produção." (MARICATO, 2013, p. 20)
} 
Com o processo de redemocratização e o fim da ditadura militar, extinto o $\mathrm{BNH}$, houve um redesenho político e institucional dos procedimentos de enfrentamento do déficit habitacional no país, onde, por exemplo, com a edição de uma nova Carta Constitucional, aos Municípios foi dada autonomia para, de acordo com as diretrizes nacionais, gerir a política urbana local. De fato, avanços legais foram expressos na Constituição Federal de 1988 que, a partir de sua edição, positivou como norma a funcionalização social da propriedade e da cidade.

A Constituição de 1988 incorporou um capítulo sobre política urbana, estruturado em torno da noção de função social da cidade e da propriedade, do reconhecimento dos direitos de posse dos milhões de moradores das favelas e periferias das cidades do país e da incorporação direta dos cidadãos nos processos decisórios relacionados a essa política. (ROLNIK, 2015, 264-265)

Entretanto, o alinhamento indiscriminado do país ao pensamento neoliberal ${ }^{19}$ e o consequente sacrifício das políticas sociais internas em favor das políticas de mercado, findou, no caminho inverso das intenções do legislador constitucional, por recrudescer a situação de pobreza e desigualdade social já presente no cenário das cidades, comprometendo sobremaneira o ideal de política urbana previsto na norma e influenciando significativamente os modelos de urbanização que, cada vez mais, se associavam ideologicamente aos padrões hegemônicos de especialização e financeirização dos espaços urbanos (ROLNIK, 2015).

Ao se buscar elementos que possam construir uma resposta satisfatória sobre os saberes que propiciaram os fundamentos do urbanismo ao longo do século $X X$, como forma de se investigar, historicamente, as origens de um discurso hegemônico, definidor de um protótipo retórico de cidade e, consequentemente, da política urbana da atualidade, tem-se que, no caso do Brasil, encontramos uma trajetória histórica que explicita um modelo de urbanização excludente, predatório e patrimonialista (ROLNIK, 2015, p. 266).

Neste processo de construção e compreensão daquele modelo de urbanização, Raquel Rolnik (2015) chama atenção para o fato de que as políticas de habitação social no Brasil jamais atravessaram, historicamente, esquemas ou arranjos de bem-estar social ${ }^{20}$, como no caso da

\footnotetext{
${ }^{19}$ O pensamento neoliberal surge na Inglaterra e nos Estados Unidos. Sua formulação, definida pelo Consenso de Washington, buscou ressignificar os ajustes nas economias de países em desenvolvimento por meio de uma agressiva política de privatizações, com a consequente proteção ao direito de propriedade e a abertura de fronteiras à iniciativa privada: "A ideia central do Consenso de Washington era de prudência macroeconômica, aliada ao capitalismo de mercado a partir da orientação externa. A política de desenvolvimento consistia em retirar qualquer intervenção do governo em favor da racionalização da economia, a partir do disciplinamento do mercado e da tendência nas escolhas prudentes na alocação de recursos externos". (SOUSA, 2011, p. 82).

20 Para Raquel Rolnik, as estratégias sócio-políticas adotadas pelos países Europeus após a segunda guerra mundial, pelas quais foram montadas políticas públicas que estruturaram um sistema de bem-estar
} 
Europa: "Nesse sentido, falar sobre a introdução de uma agenda neoliberal no país, não significa tratar do desmantelamento de uma série de direitos sociais já estabelecidos" (ROLNIK, 2015, p. 266), ao menos no caso do Brasil.

Diante desta conjuntura política, sempre vulnerável às forças do capital estrangeiro, o que se pode aferir é que, no campo da política urbana, as intenções legislativas consagradas tanto pela Constituição Federal de 1988 - esta alterada no ano de 2000, por Emenda Constitucional mediante a qual se inseriu, no artigo 60 , o direito à moradia como um direito social - , quanto pelo Estatuto da Cidade, aprovado em 2001, como norma a instituir instrumentos de política urbana, não foram suficientes para diminuir o fosso da desigualdade e da segregação social, estes sim, os grandes traços caracterizadores do modelo de cidades no Brasil.

Para Villaça (2001), a metrópole brasileira se caracteriza, marcadamente, por sua índole segregacionista, onde os espaços urbanos são definidos segundo valores de estratificação social. Para o autor, "a segregação é um processo segundo o qual diferentes camadas ou classes sociais tendem a se concentrar cada vez mais em diferentes regiões gerais ou conjuntos de bairros da metrópole" (VILLAÇA, 2001, p. 142).

Jean-Louis Harouel (1998) faz uma importante análise deste fenômeno centro $x$ periferia e suas causas. O autor compreende que o despovoamento do centro, sobretudo nas grandes cidades, é algo típico do século XX, e que, como um efeito colateral de ações de intervenção nos espaços urbanos, suas causas e consequências variam de país, para país.

As causas são várias. A proliferação de escritórios transforma alguns bairros em desertos à noite. [...] No mais, em muitas das grandes cidades europeias, o preço elevado das habitações expulsa para a periferia vastas camadas da população: operários e demais assalariados, jovens casais com filhos. A habitação no centro torna-se então um privilégio. Ao contrário, em numerosas grandes cidades americanas, o centro da cidade é ameaçado de degradação e de proletarização, enquanto os mais abastados se refugiam nas zonas residenciais suburbanas, (HAROUEL, 1998, p. 106)

No contexto do Brasil, os processos de segregação urbana não devem ser tomados numa condição de exclusividade, mas de predominância do setor segregado (VILLAÇA, 2001).

social, não encontraram no Brasil um arranjo com o qual se possa fazer uma razoável comparação. Pelo contrário, para a autora, o impulso de modernização, protagonizado pelo Brasil após a década de 60 se deu para atender exclusivamente a interesses econômicos, numa tônica que primava não pela garantia de direitos sociais, mas pelo crescimento industrial associado à depreciação e à espoliação das massas urbanas e das relações de trabalho, pela via do autoritarismo e por uma política fundiária excludente (ROLNIK, 2015). 
O mais conhecido padrão de segregação da metrópole brasileira é o do centro $x$ periferia. O primeiro dotado da maioria dos serviços urbanos públicos e privados, é ocupado pelas classes de mais alta renda. A segunda, subequipada e longínqua, é ocupada predominantemente pelos excluídos. O espaço atua como mecanismo de exclusão. (VILLAÇA, 2001, p. 143)

Ermínia Maricato (2014) reconhece que o final do século XX e início do século XXI introduziu, no cenário político e econômico do Brasil, uma realidade de transição. Para a autora, especialmente no que tange à política urbana, o direito à cidade passou a ocupar uma posição central nos debates concernentes às reformas a serem implementadas naquele campo, muito embora tais reformas devessem atender a uma política de índole desenvolvimentista ${ }^{21}$, de fortalecimento do capital privado, com forte participação de investimentos públicos.

A estratégia de fortalecimento de gigantescas empresas nacionais se combina às exigências e oportunidades oferecidas pela expansão capitalista mundial. Dentre as empresas brasileiras mais internacionalizadas então a Gerdau, a Norberto Odebrecht, a Vale, a Petrobrás, a Marco Polo Sabó, Embraer, Natura e Andrade Gutierrez. (MARICATO, 2014, p. 42)

Esta estratégia desenvolvimentista, no campo da política urbana, ganhou fortes contornos a partir do lançamento do Programa Minha Casa Minha Vida (Lei no 11.977, de 7 de julho de 2009), em 25 de março de 2009²2, destinado a impulsionar a construção de moradias e oferecer uma via de solução para problema do déficit habitacional do país, associada ao aquecimento da indústria da construção civil e seus reflexos na economia do país, numa tática de reação à anunciada crise internacional que eclodiu em 2008 (MARICATO, 2014).

Ocorre que tal política de habitação, muito embora contemplasse uma parcela de sua produção para as entidades de luta pelo direito à moradia ${ }^{23}$, em nada alterou os arquétipos de

\footnotetext{
21 "Um Estado forte que investe na construção de infraestrutura econômica e social e ainda na ampliação de conglomerados brasileiros privados, para torná-los competitivos no mercado internacional." (MARICATO, 2014, p. 41)

22 Portal Brasil, Publicado em: 30/03/2016: "Em sete anos, Minha Casa Minha Vida entrega mais de 1.000 casas por dia. O ritmo de entregas de moradias do Minha Casa Minha Vida desde seu lançamento, há sete anos, reforça o programa como a maior iniciativa para enfrentar a questão habitacional da história do País. Desde o seu lançamento, em 25 de março de 2009, foram contratadas mais de 4,2 milhões de casas. Dessas, mais de 2,6 milhões já foram entregues. Isso representa uma taxa de entrega de mais de 1.000 casas por dia; pelo menos 17 a cada hora. Em 2.562 dias de existência do programa, foram beneficiadas mais de 10,4 milhões de pessoas, que realizaram o sonho da casa própria." (PORTAL BRASIL, 2016, s/p)

${ }^{23}$ A política do Minha Casa Minha Vida Entidades (PMCMV-E), pressionada pelos movimentos populares de luta por habitação e pelo Fórum Nacional de Reforma Urbana, findou por inserir irrisórios $2 \%$ do orçamento do Programa a esta modalidade de subsídio para produção de moradias autogestionadas, para construção ou requalificação de imóveis urbanos (ROLNIK, 2015, p. 302). Em 17/05/2017, o então ministro das Cidades, Bruno Araújo (PSDB-PE), do então Governo Interino Michel Temer, revogou a portaria editada pelo governo Dilma Rousseff que autorizava a Caixa Federal a contratar a construção de até 11.250 unidades habitacionais do PMCMV-E destinadas à faixa 1 do programa, que atende famílias
} 
modelagem das cidades, vigentes no contexto do Regime Militar, permanecendo perfilhada ao velho padrão de política habitacional associada à aquisição da casa própria, da localização funcional e segregacionista e da estigmatização territorial (MARICATO, 2014).

De fato, resta configurada, numa perspectiva de análise arqueológica, novamente, um processo de reatualização de uma prática histórica de solucionar o déficit habitacional pela via da produção de moradia, paradoxalmente, todavia, mediante um processo que não passaria pela racionalidade do direito à cidade: "O PMCMV retoma a política habitacional com interesse apenas na quantidade de moradias, e não na sua fundamental condição urbana" (MARICATO, 2014, p. 73).

\section{Programa Minha Casa Minha Vida: remendo novo em pano velho?}

A lógica da segregação espacial no Brasil se associa a um modelo periférico de ocupação das cidades, sobretudo no contexto das metrópoles, num nexo de uso e ocupação do solo que não só é ratificado, como é promovido pelas políticas públicas de produção de moradia para as camadas mais pobres da população.

O Programa Minha Casa Minha Vida (PMCMV) insere-se, atualmente, no campo econômico-social de uma ação política para oferta de moradias, mediante a construção e financiamento de um vasto estoque habitacional gerenciado por regras de inserção ${ }^{24}$ que obedecem a um extenso conjunto de requisitos.

com renda mensal de até R\$ 1.800 (PLANTÃO BRASIL, 2016, s/p). Entretanto, após ser fortemente pressionado por movimentos populares, a exemplo do MTST, que mediante ações de ocupações em prédios públicos, reivindicaram o retorno daquela modalidade de investimento em moradia popular, o Governo retrocedeu (REDE BRASIL ATUAL, 2016, s/p), aprovando, em dezembro de 2016, a Resolução no 214, de 15 de dezembro de 2016, a partir da qual foram retomados os investimentos no PMCMV-E.

${ }^{24}$ Recentemente alteradas pelo Governo Federal, tais regras obedecem a novo padrão de requisitos, assim descritos: "Entenda as novas regras do Minha Casa Minha Vida:

Para poder financiar um apartamento pelo programa, o beneficiário precisa cumprir uma série de requisitos. O principal deles é a renda familiar. A partir dela, é definido (sic) os juros do financiamento, o prazo de pagamento e o tipo de imóvel.

As medidas anunciadas pelo governo mudam as regras para quem está nas faixas de renda 1,5, 2 e 3 . Para se enquadrar na primeira faixa, a renda total da família precisa ser de até $R \$ 2,6$ mil. Antes, esse limite era menor, de $\mathrm{R} \$ 2,35$ mil.

Para os que se enquadram na faixa 2, agora é preciso ter uma renda de até $\mathrm{R} \$ 4$ mil. Antes dessas mudanças, o limite era de $R \$ 3,6$ mil. Na faixa 3 , esse teto de enquadramento subiu de $R \$ 6,5$ mil para $R \$$ 9 mil. Na ponta do lápis, houve um reajuste de 7,69\%.

Essas mudanças vão permitir que mais unidades habitacionais se enquadrem no programa. No Distrito Federal, São Paulo e Rio de Janeiro, por exemplo, era possível financiar uma casa ou apartamento avaliado em até $\mathrm{R} \$ 225$ mil. Agora, o valor aumentou para $\mathrm{R} \$ 240$ mil. Esse enquadramento vale para as operações com uso do Fundo de Garantia do Tempo de Serviços (FGTS). 
O "Minha Casa Minha Vida" é, antes de tudo, uma "marca", sob a qual se organiza uma série de subprogramas, modalidades, fundos, linhas de financiamento, tipologias habitacionais, agentes operadores, formas de acesso ao produto "casa própria" - esta sim uma característica que unifica as diferentes experiências. (AMORE, 2015, p. 15)

O que diferencia o escalonamento desse programa em faixas e linhas de financiamento é o modelo de retorno, em termos de incentivo que ele pode oferecer ao mercado imobiliário. A primeira faixa comporta o que Caio Santo Amore, do Instituto de Arquitetura e Urbanismo da USP, chama de "dinheiros baratos", ou seja, trata-se de uma modalidade de financiamento que não exige retorno: “As operações financeiras são garantidas pelo Fundo Garantidor, que é lastreado por recursos da União e permite a eliminação dos seguros no custo do financiamento" (AMORE, 2015, p. 20).

Já as outras duas faixas, igualmente subsidiadas pelo Governo Federal, são financiadas com recursos do FGTS e corresponderiam a um "dinheiro mais caro" (AMORE, 2015, p.21), que exige retorno e cobra juros.

Esta diferenciação em faixas afeta sobremaneira as tipologias habitacionais do Programa, refletindo um modelo de cidade homogênea, num campo de continuidades organizado segundo os interesses do mercado de financeirização da moradia, a ponto de, mesmo tornando mais complexa e caótica a estrutura urbana das cidades, não comprometer o retorno financeiro dos empreendimentos aos seguimentos da construção civil.

Pode-se dizer que o Programa tem reforçado a lógica de conurbação, por conta da crescente aceitação da metropolização do déficit, com a implementação de empreendimentos nos municípios mais distantes do núcleo, assegurando maiores ganhos ao setor privado pela apropriação de terras mais baratas e submetendo as famílias de menor renda a morar em regiões mais distantes dos empregos, comércio, serviços, equipamentos públicos e a se deslocarem cotidianamente por longos períodos e longas distâncias. (RUFINO, 2015, p. 60).

Outro dado importante que singulariza o Programa é a identificação dos agentes a quem cabe o processo de produção e distribuição de moradia, no qual institucionalizado o protagonismo de um agente financeiro (a Caixa Econômica Federal ${ }^{25}$ ) que, em parceria com

Nas capitais do Nordeste e do Norte, será possível financiar apartamentos de até R\$ 180 mil com dinheiro do FGTS. O limite anterior era de R\$170 mil. O último reajuste para os imóveis financiados com recursos do fundo de garantia havia sido dado em 2015." (PALÁCIO DO PLANALTO, 2017, s/p)

25 "A Caixa Econômica Federal, operadora do programa, passa a se relacionar de maneira mais direta com os agentes imobiliários, oferecendo crédito imobiliário - Faixas 2 e 3: Fundo de Garantia por Tempo de Serviço (FGTS) - ou "comprando" os empreendimentos - Faixa 1: Fundo de Arrendamento Residencial (FAR). No caso da Faixa 1, os empreendimentos são ofertados a uma demanda cativa, determinada pelos cadastros definidos pelas prefeituras." (RUFINO, 2015, p. 55) 
empresas da construção civil e agentes imobiliários, e sob a chancela da administração pública, reforçam os padrões de financeirização das políticas de moradia.

Uma das mudanças mais importantes a ressaltar em relação ao PMCMV é a ausência de um agente promotor público, papel antes desempenhado por Companhias Metropolitanas de Habitação (COHAB), associações e cooperativas, responsáveis pela incorporação imobiliária e gestão dos empreendimentos. Essas instituições mantinham vínculos diretos com os poderes públicos municipais e por vezes federais, o que abria maiores possibilidades para articulação com as políticas urbanas, embora isso nem sempre acontecesse. O desenho institucional adotado pelo programa PMCMV, no entanto, inviabiliza a possibilidade de o poder público atuar como promotor e gestor do empreendimento. A instituição financeira (Caixa Econômica Federal), por um lado, e as empresas, por outro lado, ganham centralidade em detrimento dos órgãos e instituições responsáveis pelas políticas urbanas e habitacionais. (RUFINO, 2015, p. 55)

Porquanto, mais de um século depois, o mesmo padrão antiurbano e segregador pode ser reconhecido nas práticas discursivas institucionais no Brasil que, incorporando velhos métodos padronizados por uma concepção de urbanismo progressista, não se percebem afetados por técnicas de urbanificação padronizadas desde o século XIX, que comprometem as políticas urbanas tanto no âmbito nacional, quanto no âmbito local, a recrudescer a disputa por renda imobiliária.

De fato, na esfera municipal, a política habitacional, pari passu aos contornos dados pelo PMCMV, dá aos municípios, por exemplo, a tarefa de disponibilizar terrenos para a implantação do programa, cujas localizações, definidas dentro dos padrões de especulação imobiliária, geralmente se acham desacompanhadas de uma racionalidade que promova a urbanificação destas novas frentes de moradia.

Com efeito, as cidades, como hoje são, notadamente no contexto pós-segunda guerra mundial, sobretudo no caso da América Latina, foram organizadas a partir de um mesmo princípio determinante; um a priori histórico que nasce das estruturas do capitalismo moderno, propulsor da expansão do tecido urbano.

Vivem hoje uma fase pós-industrial, marcadamente afetada pelos efeitos de uma globalização difusa e descontínua que, muito embora produza crescimento, por outro lado deflagra desigualdades: "Na mesma cidade, é o mercado o responsável por reunir e organizar os diversos segmentos existentes no território com base em uma lógica urbana unitária" (GARBOSSA; SILVA, 2016 p. 62). 
Portanto, é este marco histórico-analítico importante lente de análise dos discursos jurídicos institucionais situados na temática do direito à moradia digna, sobretudo no que tange à capacidade de formularem verdades dentro da dinâmica global da cidade.

Desse modo, eis que, uma vez delineados os aspectos históricos e os padrões de criação de um saber urbanístico e suas ideais-chave, tal mapeamento histórico permite um estudo da ordem jurídico-normativa que cuida da questão do direito à moradia, pressupondo a importância de que, enquanto acontecimento arqueológico, as ideias ora discutidas permitem um maior entendimento do discurso normativo que embasa o discurso jurídico-institucional sobre as cidades. É capaz de evidenciar uma retórica que se vale de um modelo de cidade permeado por representações hegemônicas que priorizam o progresso do capital financeiro como parâmetro de solução dos conflitos sociais por moradia urbana, comprometendo sobremaneira o direito humano de morar em cidades.

\section{CONCLUSÃO}

A sobrecarga da infraestrutura urbana, longe de ser uma distorção conjuntural, revelase, a despeito da norma que regulamenta o assunto em espécie, um problema estrutural. E o cenário tende a se agravar quando se reconhece o processo de erradicação do estoque público de habitação para efeito de oportunizar a livre circulação do capital financeiro, prática cristalizada pela concessão de crédito habitacional, impulsionada por programas de aquisição de moradia (a exemplo do Programa Minha Casa Minha Vida), paralela ao declínio de investimentos estatais no setor de habitação.

Os processos de remoções que tanto são noticiados em escala global e local sintomatizam esta realidade. Pessoas são removidas de suas habitações já consolidadas, submetidas a intenções oficiais de embelezamento e saneamento da cidade, mediante ações de encilhamento, nas quais, deslocadas dos locais onde desenvolvem suas redes sócio-afetivas, são lançadas numa lista de espera para concessão de aluguel público que nem sempre se realiza a contento.

Numa descrição arqueológica que possibilitasse identificar seu acontecimento discursivo, por exemplo, para efeito de se fazer esta conjectura com os discursos institucionais, foi especulada a contribuição das ideias que forneceram base ao urbanismo, formuladas no final do século XIX e durante o século XX e que os orientam a um modelo de cidade já cunhado em uma prática discursiva progressista pretérita. 
Tal constatação inicial forneceu ao presente trabalho, ao menos para a construção de seu trajeto, a intuição de que a arqueologia foucaultiana possibilitaria com que se dotasse de significado (o a priori histórico) o modelo urbanístico vigente.

Associado a um vasto referencial teórico que abordou a questão das políticas urbanas, permitiu-se a abertura de diferentes possibilidades argumentativas dentro de uma mesma temática - o direito à cidade, o direito à moradia e o direito à vida urbana, por exemplo, dentro de uma prática de planejamento urbano -, a partir das quais tornou-se possível "reanimar temas já existentes", definindo, por conseguinte, um "campo de possibilidades estratégicas" (FOUCAULT, 2012, p. 45) para o exercício da função enunciativa, onde a arqueologia permitiu a análise das condições históricas que possibilitaram o aparecimento dos discursos urbanísticos.

Critério fundamental do estudo empreendido foi o de que, uma vez fixados os elementos de um acontecimento discursivo, identificado pelas escolas fundantes da política urbana do século XX, tal mapeamento pode, em contrapartida, colaborar para uma apropriada investigação do marco legal dos diversos diplomas normativos vigentes, promulgados acerca da questão da política urbana, com especial destaque para a Constituição Federal e o autodenominado Estatuto da Cidade, Lei 10.257, de 10 de julho de 2001, especialmente no que tange às diretrizes da política urbana, definidas no artigo 2ㅇdaquela norma, sob o ponto de vista de sua eficiência e aplicação prática.

O que se vê é a predominância de uma prática discursiva referenciada por um a priori histórico que condiciona uma ideia de cidade que impõe hegemonias espaciais que se conformam e cristalizam importantes contradições quando analisadas pela lente da legislação urbanística, assim impondo um arquivo do que pode ser dito em relação à conformação dos espaços urbanos e dos interesses priorizados.

\section{REFERÊNCIAS}

AMORE, Caio Santo. Minha casa... e a cidade? Avaliação do Programa Minha Casa Minha Vida em seis estados brasileiros. AMORE, Caio Santo; SHIMBO, Lúcia Zanim; RUFINO, Maria Beatriz Cruz (orgs). 1. ed. Rio de Janeiro: Letra Capital, 2015.

BARRETO, Lima. Os Bruzundangas. 2. ed. São Paulo: Martin Claret, 2013.

Recordações do Escrivão Isaías Caminha. São Paulo: Poeteiro Editor Digital, 2014. Disponível em: <http://web.archive.org/web/20161202125427/http://www.projetolivrolivre.com/Lima\%20Barr eto\%20-\%20Recordacoes\%20do\%20escrivao\%20lsaias\%20Caminha\%20\%20lba\%20Mendes.pdf> Acesso em 06.abr.2017. 
BENEVOLO, Leonardo. História da Cidade. São Paulo: Perspectiva, 2015

BONDUKI, Nabil Georges. Origens da habitação social no Brasil. Análise social, p. 711-732, 1994. Disponível em: <http://www.jstor.org/stable/41011028?seq=1\#fndtnpage_scan_tab_contents>. Acesso em: 11.jul.2017.

BRASIL. Programa Minha Casa Minha Vida - PMCMV. Lei no 11.977, de 7 de julho de 2009. Disponível em < http://www.planalto.gov.br/ccivil_03/_ato2007-2010/2009/lei//11977.htm> Acesso em 04.ago.2016.

CASTRO, Edgardo. O vocabulário de Foucault: um percurso pelos seus temas, conceitos e autores. Belo Horizonte: Autêntica Editora, 2016.

CHOAY, Françoise. O urbanismo. Utopias e realidades. Uma antologia. Estudos, volume 67. São Paulo: Perspectiva, 2015.

DAMATTA, Roberto. Carnavais, malandros e heróis: para uma sociologia do dilema brasileiro. 6.ed. Rio de Janeiro: Rocco, 1996.

DEÁK, Csaba. Acumulação entravada no Brasil e a crise dos anos 1980. In: DEÁK, Csaba; SCHIFFER, Sueli Ramos (orgs.). O processo de urbanização no Brasil. São Paulo: Editora da Universidade de São Paulo, 2010.

DE AZEVEDO, Sergio. Vinte e dois anos de política de habitação popular (1964-86): criação, trajetória e extinção do BNH. Revista de Administração Pública, v. 22, n. 4, p. 107-119, $1988 .$. Disponível em: < http://bibliotecadigital.fgv.br/ojs/index.php/rap/article/view/9391/8458>. Acesso em: 05.jul.2017

FOUCAULT, Michel. A Arqueologia do Saber. Rio de Janeiro: Forense Universitária 2012. A Ordem do Discurso. São Paulo: Ed. Loyola, 2014.

FURTADO, Celso. Brasil: A construção interrompida. Rio de Janeiro, Paz e Terra, 1992.

GARBOSSA, Renata Adriana; SILVA, Rodolfo dos Santos. O Processo de Produção do Espaço Urbano: impactos e desafios de uma nova urbanização. Curitiba: InterSaberes, 2016.

GEHL, Jan. Cidades para Pessoas. São Paulo: Perspectiva, 2015.

HALL, Peter. Cidades do Amanhã. São Paulo: Perspectiva, 2016.

HAROUEL, Jean-Louis. História do Urbanismo. Campinas: Papirus, 1998.

HOLANDA, Sergio Buarque de. Raízes do Brasil. 26. ed. São Paulo: Companhia das Letras, 1995.

JACOBS, Jane. Morte e Vida de Grandes Cidades. 3. - ed. São Paulo: Editora WMF Martins Fontes, 2014.

KOWARICK, Lúcio. A espoliação urbana. São Paulo: Paz e Terra, 1993. 
LE CORBUSIER. Planejamento Urbano: coleção debates. São Paulo: Perspectiva, 2004.

LEFEBVRE, Henri. Direito à Cidade. São Paulo: Centauro, 2011.

MANZI FILHO, Ronaldo. Duas noções de a priori histórico: a tradição e o arquivo - A concepção de uma "anti-crise" de Michel Foucault. Revista Philósophos, v. 19, n. 1, 2014. Disponível em < http://web.b.ebscohost.com/abstract?direct=true\&profile=ehost\&scope=site\&authtype=crawle r\&jrnl=19822928\&AN=98738780\&h=kpOS17xi3B10ol76ro4JHpWckcQZNGnwqSlgnU\%2bbp\%2b eMX9UuxGdAi\%2bwGGi74\%2fWO47MJNO\%2bMgpjaikFsMmM4A7Q\%3d\%3d\&crl=c\&resultNs= AdminWebAuth\&resultLocal=ErrCrINotAuth\&crlhashurl=login.aspx\%3fdirect\%3dtrue\%26profile \%3dehost\%26scope\%3dsite\%26authtype\%3dcrawler\%26jrnl\%3d19822928\%26AN\%3d9873878 0> Acesso em 19.jul.2017.

MARICATO, Ermínia. Brasil, cidades: alternativas para uma crise urbana. Petrópolis: Vozes, 2013 O impasse da política urbana no Brasil. Petrópolis: Vozes, 2014.

MILARÉ, Édis. Direito do Ambiente. 9. Ed. São Paulo: Editora Revista dos Tribunais, 2014.

PALÁCIO DO PLANALTO. Presidência da República. Entenda as novas regras do Minha Casa Minha Vida. Publicado em: 06.fev.2017. Disponível em: <http://www2.planalto.gov.br/acompanhe-planalto/noticias/2017/02/entenda-as-novas-regrasdo-minha-casa-minha-vida>. Acesso em: 06.jul.2017

PORTAL BRASIL. Infraestrutura. Em sete anos, Minha Casa Minha Vida entrega mais de 1.000 casas por dia. Publicado em: 30.mar.2016. Disponível em: < http://www.brasil.gov.br/infraestrutura/2016/03/em-sete-anos-minha-casa-minha-vidaentrega-mais-de-1-000-casas-por-dia>. Acesso em: 07.jul.2017.

REDE BRASIL ATUAL. MTST ocupa Ministério das Cidades por verbas do Minha Casa, Minha Vida. Publicado em: 29.nov.2016. Disponível em: < http://www.redebrasilatual.com.br/politica/2016/11/mtst-ocupa-ministerio-das-cidades-embrasilia-8601.html>. Acesso em: 07.jul.2017.

ROLNIK, Raquel. Guerra dos Lugares: a colonização da terra e da moradia na era das finanças. São Paulo: Boitempo, 2015.

RUFINO, Maria Beatriz Cruz. Minha casa... e a cidade? avaliação do Programa Minha Casa Minha Vida em seis estados brasileiros. AMORE, Caio Santo; SHIMBO, Lúcia Zanim; RUFINO, Maria Beatriz Cruz (orgs). 1. ed. Rio de Janeiro: Letra Capital, 2015.

SEVCENKO, Nicolau. A Revolta da Vacina. São Paulo: Cosac Naify, 2010.

STEDILE, João Pedro; SAMPAIO, Plínio de Arruda. História, crise e dependência do Brasil. Cartilha no 3. São Paulo: Movimento Consulta Popular, 2003. Disponível em: <http://www.consultapopular.org.br/sites/default/files/cartilha\%2003\%20\%2OHist\%C3\%B3ria\%20crise\%20e\%20dependencia\%20do\%20Brasil.pdf >. Acesso em: 05.jul.2017 
SOUSA, Monica Teresa Costa. Direito e desenvolvimento: uma abordagem a partir das perspectivas de liberdade e capacitação. Curitiba: Juruá, 2011.

SOUZA, Marcelo Lopes de. Mudar a Cidade: uma introdução crítica ao planejamento e à gestão urbanos. Rio de Janeiro: Bertand Brasil, 2013.

VIANA, Nildo. O significado político da Comuna de Paris. Em Debate, n. 6, p. 60-82, 2011. Disponível <http://stat.saudeetransformacao.incubadora.ufsc.br/index.php/emdebate/article/view/877/13 22>. Acesso em 22.mai.2017.

VILLAÇA, Flávio. Espaço intra-urbano no Brasil. São Paulo: Studio Nobel: 2001.

Uma contribuição para a história do planejamento urbano no Brasil. In: DEÁK, Csaba; SCHIFFER, Sueli Ramos (orgs.). O processo de urbanização no Brasil. São Paulo: Editora da Universidade de São Paulo, 2010.

YAMAWAKI, Yumi; SALVI, Luciane Teresa. Introdução à Gestão do Meio Urbano. Curitiba: InterSaberes, 2013.

Trabalho enviado em 19 de janeiro de 2018.

Aceito em 25 de março de 2018. 